\title{
BALANCING WESTERN LEGAL CONCEPTS, ASIAN ATTITUDES AND PRACTICAL DIFFICULTIES - A CRITICAL EXAMINATION OF HONG KONG'S RESPONSE TO THE REFUGEE PROBLEM
}

\author{
Roda Mushkat
}

\section{INTRODUCTION}

It is fashionable to highlight Hong Kong's unique economic and political features. This paper is not inconsistent with this trend for it aims to explore the territory's approach to the refugee issue by focusing on constraints inherent in its status as a British dependency, a would-be semi-autonomous part of the People's Republic of China (PRC) and an Asian politico-economic entity.

Such a tripartite identity is inevitably a source of conflicting demands which are not easy to reconcile in practice. The British, Chinese and Asian traditions tend to diverge rather than converge - a problem compounded by the fact that the refugee question can be tackled from multiple analytical perspectives.

There are, of course limits beyond which the three-dimensional perspective cannot legitimately be stretched. The international legal norms pertaining to the refugee issue may be characterised by a degree of ambiguity, but they offer a viable framework for assessing specific practices. An attempt will be made, therefore, to examine the Hong Kong reality in the light of generally recognised principles of international refugee law.

* LL.B. (Jeru); LL.M. (Well), LL.D. (Pret.), Dip. Intl. Law (Man), Member of the Israel Bar, Senior Lecturer, Faculty of Law, University of Hong Kong.

(c) 1993 Kluwer Academic Publishers. Printed in the Netherlands. 


\section{ADMISSION OF ASYLUM SEEKERS}

\subsection{International Rules}

The basic rule pertaining to admission of refugees is laid down in Art. $33(1)$ of the 1951 UN convention Relating to the Status of Refugees. ${ }^{1}$ It stipulates that " $[n]$ o Contracting State shall expel or return ('refouler') a refugee in any manner whatsoever to the frontier of territories where his life or freedom would be threatened on account of his race, religion, nationality, membership of a particular social group or political opinion".

The principle - which in its most restrictive interpretation was taken to mean "no return, no expulsion" - has been extended to include "no rejection at the frontiers" where the end result would be the same (i.e. compulsory return to the country where the refugee may be subjected to persecution). ${ }^{2}$ It is further considered that as a "logical and necessary corollary" of an otherwise incomplete regime of non-refoulement, a duty to provide temporary refuge is also implied. ${ }^{3}$

The universal recognition of the principle in various multilateral instruments, General Assembly resolutions and numerous conclusions and recommendations of international conferences coupled with extensive State practice and opinio juris has, moreover, reinforced the view that non-refoulement has matured into a norm of customary international law binding on all members of the international community whether or not they are party to the Refugee Convention. ${ }^{4}$

Hence, Hong Kong, which is not a party to the Refugee Convention, is bound by the non-refoulement proscription and is legally obliged to provide temporary refuge to asylum seekers, if refusal would involve their re-

1. 189 UNTS 137; hereafter the Refugee Convention.

2. Note commentary by A.GRAHL-MADSEN, Territorial Asylum (Almquist \& Siksell, 1980) at p.74 that the rule of non-refoulement as ordinarilly formulated in Art. 33 did incorporate such a prohibition, in particular with regard to States sharing a common frontier with the country from which the refugees have fled. In Grahl-Madsen's opinion subsequent developments have simply served the function of clarifying the provision in question.

3. See G.S.Goodwin-GILL, "Entry and Exclusion of Refugees", Michigan Yearbook of International Legal Studies (1982), p.306. See also International Institute of Humanitarian Law, Report of the Round Table on the Problems Arising from Large Numbers of Asylum Seekers (1981) para 9: "The first act of protection which the asylum-seeker needed was admission in the territory of the State of arrival, in accordance with the generally recognised principle of non-refoulement and, therefore, of non-rejection at the border."

4. For an analysis of the status of non-refoulement as a principle of customary international law, see G.S.GoodWIN-GILL, The Refugee in International Law (Clarendon Press, 1983), pp.97-100; P. HYNDMAN, "An appraisal of the development of the protection afforded to refugees under international law", 1 Lawasia N.S. (1981), p.229; P.HYNDMAN, "Asylum and Non-Refoulement- are these obligations owed to refugees under international law?", 55 Phil. L.J. (1982) p.43; R.MUSHKAT, "Human rights under temporary refuge", 62 Revue de droit international (1984), p.169. 
turn to a country from which they have fled or would otherwise expose them to serious danger (e.g. on the high seas).

The territory's international obligations with respect to refugees are further reinforced by conventional undertakings in the form of (a) a pledge to maintain Hong Kong as a "country of first asylum" given at the UN Meeting on Refugees and Displaced Persons in South East Asia (Geneva, 20-21 July 1979); ${ }^{5}$ and (b) a reaffirmation at the International Conference on Indochinese Refugees (Geneva, 13-14 June 1989) of a commitment to continue to allow safe arrival and provide temporary refuge to asylum seekers from Vietnam and Laos. ${ }^{6}$

No definition of "country of first asylum" has, however, been universally accepted. A widespread usage" may be said to have developed ${ }^{7}$ for "excluding from consideration the cases of those who have found or are deemed to have found asylum or protection elsewhere, or who are considered to have spent too long in transit. ${ }^{n 8}$

Yet, to eschew the problem of "refugees in orbit" ${ }^{\text {"9 }}$ States are urged to adhere to the recommendation that "asylum shall not be refused solely on the grounds that it could be requested from another State. ${ }^{110}$ In any event, under no circumstances, is the principle of non-refoulement to be compromised and where there is no readmittance agreement with a purported "country of first asylum" the territory where refuge is sought should allow asylum seekers to enter provisionally pending suitable arrangements. ${ }^{11}$

\subsection{The British Position}

The UK is a party to the 1951 Refugee Convention and its 1967 Protocol. ${ }^{12}$ However, there is not a distinct statute governing refugees and the relevant provisions form part of general immigration law which consists of

5. See Annual Review of UN Affairs 1979, pp.234-5.

6. See M.KNowLES, The International Conference on Indochinese Refugees and its Aftermath (Refugee Policy Group, 1989).

7. See G.Fourlanos, Sovereignty and the Ingress of Aliens (Almquist \& Wiksell Int'l, 1986) at p.155.

8. Goodwin-GiLL, supra n.4 at p.53.

9. Defined as refugees who, although not returned to a country where they are liable to persecution are referred from one State to another in a constant quest for asylum. See G.MELANDER, "Refugees in Orbit", 16 AWR Bulletin (1978), p.59.

10. Resolution adopted by the Round Table on "Refugees in Orbit" (Florence, Italy, 4-6 June 1979) para. 3, repr. in Round Table on "Refugees in Orbit" (International Institute of Humanitarian Law, HCR/120/27/79 (1979)) at pp.83-4.

11. See UNHCR recommendation that a refugee that has applied for asylum should be permittted to remain in the country pending a decision: EXCOM Conclusion No. 8 (XXVIII), Determination of Refugee Status, para (e)(vii).

12. (1954)UKTS No. 39, Cmnd. 9171; (1969) UKTS No. 15, Cmnd. 3906. 
rules, regulations, procedures and policies of the Home Office (the immigration authority).

Britain's obligation of non-refoulement is thus given domestic effect by the Statement of Changes in Immigration Rules (1983) ${ }^{13}$ which provides under a section entitled "asylum" that "[s]pecial considerations arise where the only country to which a person could be removed is one to which he is unwilling to go owing to well founded fear of being persecuted... Any case in which it appears to the immigration officer as a result of a claim or information given by the person seeking entry at a port that he might fall within the terms of this provision is to be referred to the Home Office for decision... Leave to enter will not be refused if removal would be contrary to the provisions of the Convention and Protocol Relating to the Status of Refugees... (Rule 73). Having entered, "[a] person may apply for asylum in the United Kingdom on the ground that, if he were required to leave, he would have to go to a country to which he is unwilling to go owing to well founded fear of being persecuted..." (Rule 134.

It appears, however, that the Secretary of State for Home Affairs takes, on the one hand, a strict view of the "first asylum principle" as thought to be implied by the word "directly" in Art. 31 of the Refugee Convention and, at the same time, a "liberal" approach to the "other" country to which an asylum seeker should address his request. Thus, an application for asylum from a national of Uganda who sought leave to enter the UK from Kenya was rejected by the Home Secretary on the ground that the applicant came from a "safe country" (Kenya) which, as a signatory to the 1951 Convention, would not knowingly remove a Ugandan citizen to Uganda if there was reason to believe he would be persecuted there. The House of Lords accepted the existence of a general "international practice" that a person arriving from country A claiming to be a refugee from country $B$, where country A is a party to the Convention, could be returned to country A whose responsibility it is to investigate his claim to refugee status. The court nevertheless emphazised that the effect of Art. 33 of the 1951 Convention was to prohibit the removal of a person who was a refugee from the State of nationality to a third country if it was likely that the third country would in turn return him to the State of his nationality. The court conceded that it was for the Secretary of State to determine whether the danger of such an eventuality occurring was sufficient to involve a potential breach of Art. 33 but held that the question had not received adequate attention by the Secretary of State in the particular case. ${ }^{14}$

More recently, the Home Secretary refused to consider applications

13. H.C.169 - made under Section 3(2) of the Immigration Act 1971.

14. In re Misisi, [1987] 1 AC 514, pp.532-4 (per Lord BRIDGE), pp.537-8 (per Lord BRANDON). 
from asylum seekers who arrived at the UK from Lebanon and directed their removal to Brazil based on the fact that the applicants had visas for admission to Brazil, held tickets for travel to Brazil and had no connection with the UK and that it was reasonable to expect them to apply for asylum in Brazil. Applications for judicial review against the decision of the Home Secretary were, however, allowed by a judge of the Queen's Bench Division in the light of the UK's obligation under the 1951 Convention and in accordance with the "principle of first asylum" laid therein and supported by international practice. The court held that the Home Secretary acted unlawfully in directing the removal to Brazil since he had no cause to believe that the applicants would, as distinct from should, be admitted to that country. ${ }^{15}$

The restrictive approach reflected in the Home Secretary's decisions alluded to above coupled with legislation such as the Immigration (Carriers' Liability) Act 1987 (which imposes criminal penalties on those who carry into the UK aliens without proper documentation for lawful entry) has, doubtless, had the effect of putting "substantial obstacles in the path of refugees wishing to come [into the UK]. ${ }^{16}$

The Government has nonetheless insisted (and, strictly speaking, correctly) that visa requirements and carrier sanctions are not inconsistent with its obligations under the Refugee Convention ${ }^{17}$ and that it was following, on the whole, a "British tradition of taking in those fleeing persecution. ${ }^{\text {"18 }}$

15. Regina $v$. Secretary of State for the Home Department, Ex parte Yassime \& Others, The Times, 9 March 1990, p.4.

16. Judgement, Ex parte Yassime, loc.cit. As elaborated by Mr. Justice SCHIEMANN, “[o]ne could not get a visa on the basis of being a refugee in the country where one was being persecuted because at that stage one was arguably not outside the country of one's nationality and therefore did not fall within the definition of refugee and there was no provision for such a situation in the Immigration Rules. By reason of the 1987 Act, carriers were disinclined to convey those without a visa."

17. See H.C.HANSARD, Vol. 112, 711-2, 16 March 1987. See, however, the argument put forward by $\mathrm{E}$ Feller that while "States have a legitimate interest in controlling irregular migration and a right to do so through appropriate border measures, ... they are in breach of international obligations towards refugees where such measures hinder access both to status determination procedures and to asylum from persecution": "Carrier sanctions and international law", 1 IJRL (1989) p.48. See also A.RuF,, "The Immigration (Carrier's Liability) Act 1989: its implications for refugees and airlines", 1 IJRL (1989), p.481 - for a view that the procedural measures introduced under the Act undermined the substantive right of refugees to claim asylum and enable the UK to evade its international obligations towards relugees.

18. Home Affairs Report, cited in T.HowLAND, "A comparative Analysis of the Changing Definition of a Refugee", 5 Human Rights (1987), p.33,58n. Note also that in 1982 approximately 5000 people applied for political asylum in Britain from over 60 nations and nearly all were allowed to stay: G.S.GILBERT, "Right of asylum: A change of direction", 32 ICLQ, (1983) 633n. 


\subsection{Regional Attitudes}

It is noteworthy that the countries in the region particularly affected by refugee influxes are not parties to the 1951 Refugee Convention or its 1967 Protocol. ${ }^{19}$ They have nonetheless undertaken an internationally binding obligation to provide first asylum to refugees from Indochina. ${ }^{20}$

It should also be pointed out that while regional governments have not incorporated the principle of non-refoulement in domestic legislative enactments or appropriate administrative policies and instructions, in practice they have generally demonstrated readiness to abide by it. $^{21}$ Temporary refuge has been offered in the region to over 1.5 million Indochinese asylum seekers since 1975. Even Singapore, which made clear at the outset that it would not permit ships carrying Indochinese refugees to enter its waters, has accepted the so-called "first port of call principle" which has developed in the South East Asia region. ${ }^{22}$ Accordingly, it allows disembarkation of asylum seekers rescued by vessels whose next scheduled port is Singapore (subject to written guarantees given by the Government of the flag state of the government of a third country of resettlement within three months of arrival).

This is not to say that the principle of non-refoulement has been scrupulously observed in the region. In particular, measures employed by some countries to prevent boats landing ("push-offs") ${ }^{23}$, although by strict interpretation not a violation of the principle - if not directly effecting the return of refugees to a country in which they may be endangered - are scarcely consistent with its spirit.

Yet, on no occasion have regional governments denied the binding nature of the principle of non-refoulement and have been at pains to justify "push-back" practices as general protective mechanisms against foreign il-

19. Note, however, accessions by the Philippines (on 22 July 1981), Japan (on 3 Oct. 1981) and the People's Republic of China (on 24 Sept. 1982).

20. Both in 1979 and in 1989 at the International Conferences on Indochinese Refugees and Displaced Persons.

21. See V.MUNTARBHORN, "Displaced persons in Thailand: Legal and national policy issues" in Round Table of Asian Experts on Current Problems in the International Protection of Refugees and Displaced Persons (International Institute of Humanitarian Law, 1980) [hereafter: "Asian Experts Report 1980"]165 ff; R.SOEROSO, "Indonesia: Refugees and displaced persons - the Asian practice", ibid. at $118 \mathrm{ff}$; Y.KAWASHIMA, "Japanese legislation with respect to the protection of refugees", ibid. at $130 \mathrm{ff}$; note that Japan in fact incorporated non-refoulement in a new law introduced upon Japan's accession to the Refugee Convention: the Immigration Control and Refugee Recognition Act 1982. Under Art. 18(2) it "would be appropriate to allow the person [fleeing from a territory which was feared to be harmful to the person's life, physical being, or physical liberty] temporary landing"; Art. 53 prohibits compulsory return in case of deportation to a territory with respect to which a person has a well-founded fear of persecution on account of race, religion, political opinion, etc.

22. See M.ChANG, "Refugees and displaced persons: the Singapore experience", in: Asian Expert Report 1980, supra n.21 at $180 \mathrm{ff}$. 
legal intruders (e.g. fishermen) into territorial waters ${ }^{24}$ or as a mere "redirection of passengers to other countries that could help them to reach their desired place of final destination. ${ }^{{ }^{25}}$ The position has also been advanced that "first asylum" obligation may be discharged by supplying asylum seekers with "humanitarian aid", i.e. food, fuel, medicine and, where necessary, new vessels for ontoward journey. ${ }^{26}$

Generally, while not invoked as an express exception to the principle of non-refoulement, practical difficulties coupled with frustration over slow pace of resettlement and the unresolved issue of repatriation have given rise to more rigid admission policies ${ }^{27}$ and to tactics undermining the principle. $^{28}$

23. In early 1988 the Thai authorities organised a blockade to intercept arriving Vietnamese boats, redirecting them towards Malaysia - see US Department of State Bureau for Refugee Programs, World Refugee Report (1989) at p.31; "confirmed reports from reliable sources revealed 10 separate incidents of push-backs [by Indonesia] involving 573 persons" - J.M. DILLER, In Search of Asylum: Vietnamese Boat People in Hong Kong (Indochina Resource Action Centre, 1988 [hereafter: IRAC Report] at p.14; according to diplomats and UNHCR officials since May 1989 more than 5000 Vietnamese refugees have been towed out to sea by the Malaysian authorities - see "US criticizes Malaysia for Viet policy", South China Morning Post [SCMP] 19 Aug. 1990; the numbers have shot up to 8700 at last count - see "Malaysia to send back all Viets" ${ }^{n}$ SCMP 16 June 1990; see also reports in SCMP 13 Aug. 1989 and 1 Sept. 1989 concerning the forcing back into international waters of Vietnamese boats by South Korean maritime police.

24. See "Major, Mahathir warn of forced repatriation soon," SCMP 16 Oct. 1989 (citing Malaysian Prime Minister).

25. See A.BoyD, "Asia Boat People on Cruise to Nowhere", SCMP 27 Apr. 1990.

26. See Boyd, ibid. See also S.AzAm \& M. VATIKIOTIS, "For those in peril"”, Far Eastern Economic Review [FEER] 3 May 1990, pp.8-9; "Malaysia denies boat people turned away", SCMP 28 June 1990.

27. For example, the stance taken by the Philippines recently in refusing entry to Vietnamese boat people rescued by American ships unless a firm US guarantee was provided that they would be resettled within a certain period of time: see "Manila refuses entry to 101 boat people”, SCMP 6 June 1990; “Manila bars second US ship with Viets”, SCMP 14 June 1990. The Philippine Government eventually allowed the stranded Vietnamese ashore after receiving assurances that all refugees in the Philippines would be resettled elsewhere in 3 years: "Philippines lets Viets come ashore", SCMP 15 June 1990; similar assurances were extracted from the Canadian Government prior to permission to disembark given by the Philippine Government to Vietnamese rescued by a Canadian vessel: "Refugee deal struck", SCMP 24 June 1990. Another group of Vietnamese boat people rescued by a Taiwanese ship in international waters off Thailand were not given permission to land and shuttled back and forth to "unfriendly receptions" in Taiwan, Hong Kong and Thailand (the latter two refusing to accept responsibility because they were not "first port of call"): see J.LEUNG, "Next stop Bangkok for unwanted boat people", SCMP 12 June 1990; the troup was finally allowed to disembark in Taiwan after the Philippine Government agreed to accept them following pleas from the UNHCR: "Taiwan allows Viet to land", SCMP 19 June 1990.

28. Such as the ultimatum issued by the six ASEAN countries to the US that unless Washington agrees to force repatriation of Vietnamese people screened out as non-refugees, or establishes a holding centre for them the first asylum countries of Asia will no longer offer refuge to boat people: see M. CHUGANI, "Refugee ultimatum at impasse”, SCMP 16 June 1990. 


\subsection{The Hong Kong Approach}

As noted earlier, Hong Kong is not a party to the Refugee Convention ${ }^{29}$ nor, like other Asian countries, has it given legislative effect to its international obligations concerning admission of refugees.

The territory seems, however, to fare better than its regional counterparts in terms of practical observance of non-refoulement. As passionately put by the former British Minister of State, Foreign and Commonwealth Office with Responsibility for Hong Kong Affairs (Francis Maude), "since the whole process began in the 1970 s no fewer than 170,000 asylum seekers from Indo-China have arrived in Hong Kong. To Hong Kong's eternal honour, that tiny territory - the most crowded part of the globe - has not turned away a single one. All have been given shelter.... ${ }^{30}$

Notwithstanding regional manifestations of "compassion fatigue" the Hong Kong Government has reaffirmed its commitment to act as a country of first ${ }^{31}$ asylum, albeit not out of strong legal convictions. Pragmatic considerations seem to have largely replaced the initial humanitarian sentiments which had underlied the Government's policy of offering refuge to Indochinese boat people in the first years of the refugee influx from Vietnam. ${ }^{32}$ Apart from highlighting logistic problems, ${ }^{33}$ the current government is particularly concerned to maintain international goodwill both

29. The Convention, signed and ratified by the UK, has not been extended to the territory because of constraints inherent in the UK-China relationship regarding Hong Kong. See also H.L. Debates, Vol.460, Col.968 (27 Feb. 1985) for remarks by the Parliamentary Under-Secretary of State for the Armed Forces, Lord TREFGARNE, that "it was decided not to extend the Convention to Hong Kong because of the territory's small size and geographical vulnerability to mass illegal immigrants." He added that "[t]he 1967 Protocol was applied only to those territories to which the 1951 Convention was extended" and that "[t]he Hong Kong Government nevertheless co-operates fully with the Office of the UNHCR."

30. H.C. Debates, 1505 Weekly Hansard, Col. 270 (19 Dec. 1989).

31. If it is established that the asylum seekers "settled" in the PRC prior to arrival in Hong Kong, they are classified as "illegal immigrants" and repatriated subject to the Chinese Government's agreement to receive them back.

32. See, e.g., the Governor's response to a question enquiring whether Hong Kong might "shut its doors" and "tow the refugees back to sea" if their flow became heavy: "I do not know how you can shut the doors to someone coming in a wooden boat who has made a voyage across the South China Sea. You can't shut the doors unless you shoot." Reported in SCMP 20 June 1979.

33. As stated by the Secretary for Security in a reply to a question of a Legislative Councillor, "a decision to adopt a policy which involves the pushing-off or the re-direction of Vietnamese boat people would be hard to make and difficult to implement. Anyone advocating such a policy should bear in mind the full implications as asking police officers to carry out a policy which might result in the loss of life". Legislative Council Proceedings [LegCo Proc] 25 Oct. 1989 at p.99. 
with respect to immediate refugee issues ${ }^{34}$ and commercial interests ${ }^{35}$ and in an effort to promote Hong Kong as an international city, as well as further develop and reinforce the territory's reputation as a liberal and humane place in the run-up to 1997.36

At the same time, there has been consistent agitation locally for an end to the first asylum policy from the public at large ${ }^{37}$ through the district board level ${ }^{38}$ to the legislature.$^{39}$ Hong Kong representatives have also put the territory's name to a joint statement by regional first asylum countries to the effect that "[i]n the event of failure to agree on an immediate solution to the VBP (Vietnamese Boat People) problem, countries of temporary refuge must reserve the right to take such unilateral action as they deem necessary to safeguard their national interests, including the abandonment of temporary refuge. ${ }^{\text {"40 }}$

It is reasonable to assume, however, that the deterrence strategies threatened are more a plea for burden-sharing than an assertion of legal rights. It is also unlikely that the threat will be translated into practice by Hong Kong. The Government's stance remains that "ending first asylum would be a very difficult policy to implement in a humane manner; ...that it is very hard to see it working and being effective; and... that it is proba-

34. In an exclusive "state of the nation" interview, the Chief Secretary emphasised the substantial impact an abandonment of the first asylum principle would have on Hong Kong's ability to deal with the boat people problems in any international forum - see C.DOBSON, "Army to take control of one Viet camp", SCMP 5 May 1990.

35. See Governor's Address: "[Abandoning the first asylum principle] would also affect international attitudes towards Hong Kong in other areas, such as trade, where we have important interests"LegCo Proc, 11 Oct. 1989, at p.19.

36. See M. BARRow (Legislative Councillor), "A Solution to the Exodus”, SCMP 23 June 1990.

37. A signature campaign for the abolition of first asylum policy was embarked upon by Tuen Mun residents and the Federation of Civil Service Unions (FCSU) during an overnight sit-in outside Tuen Mun Town Hall after a mass rally attended by about 2000 people: see C.WoNG, "Residents want policy scrapped", SCMP 13 Aug. 1989. The Joint Committee of the New Territories Societies (consisting of more than 40 community organisations) petitioned the Governor, urging him to scrap Hong Kong's status as a port of first asylum-S.Y.WA, "Groups plan lobby against camp policy", SCMP 24 Aug. 1989. A similar petition was submitted to Government House by the Hong Kong Federation of Trade Unions: F.MACMAHON, "Unions protest at boat people", SCMP 25 Sept. 1989. See also B. FoNG, "Call to scrap first asylum policy: Poll", SCMP 25 Aug. 1989, reporting on the results of a survey conducted by an independent pollster in conjunction with a Radio Television HK (RTHK) public affairs programme: $84 \%$ of 535 people interviewed said they wanted a halt to the first asylum policy.

38. See "Call to scrap port of first asylum policy", SCMP 26 Oct. 1989, concerning the petition to the Governor from the Joint Districts Concern Group on Vietnamese Refugees and Boat People. The same group also sent a letter to the British Foreign Secretary urging the review of first asylum policy: K. CHEN, "Demand for review of asylum policy", SCMP 17 Jan. 1990.

39. At a debate on "Vietnamese Boat People", held in the Legislative Council on 29 Nov. 1989, all speakers (with the exception of one member) called for the revocation of the first asylum policy: LegCo Proc, pp. 442, 443, 446, 450-1, 457-8, 467, 474-5, 483-4, 490.

40. Cited in S.GREEN, "Playing it safe over first asylum", SCMP 23 May 1990. Note, however, lobbying effort of Hong Kong at a recent ASEAN working group meeting for the continuation of first asylum policy: F.MACMAHON, “Asylum plea for ASEAN meeting”, SCMP 25 July 1990. 
bly not in Hong Kong's wider interests. ${ }^{n 41}$ A rider is nonetheless attached to official statements on the subject to the effect that positions may change if limits on the "ability to cope" are transcended. ${ }^{42}$

\subsection{Evaluation}

While Hong Kong's practice with respect to temporary admission of asylum seekers has hitherto been in general accord with prevailing norms ${ }^{43}$, claims to potential derogation from international rules have been raised and the degree of their validity merits assessment.

In particular arguments grounded in "inability to cope" or practical constraints ${ }^{44}$ have brought to the fore the question "whether there is a 'tipping point' at which the influx becomes so costly and disruptive to the state of refuge that its obligations are discharged and it becomes entitled to refuse new entrants. ${ }^{n 45}$

The 1951 Refugee Convention has recognised only "danger to the security of a State" and the "conviction by a final judgment of a particularly serious crime" as legitimate exceptions to the prohibition on "refoulement". ${ }^{46}$ The 1967 Declaration on Territorial Asylum adopted by the UN General Assembly ${ }^{47}$ similarly refers to exceptions "only for overriding reasons of national security or in order to safeguard the population. ${ }^{48}$

Needless to say, "national security" is the "slipperiest of concepts, fre-

41. As relayed by Hong Kong's Refugee Co-ordinator to S. GREEN, ibid.

42. See ibid.

43. Note, however, possible "indirect" violation of "non-refoulement" through arrangements between Hong-Kong and the PRC under which the latter intercepts boat people en route to Hong Kong. See V.WONG and J.NIP, "Beijing may intercept boat people flow at sea", SCMP 17 Feb. 1990; F. WONG, "China sent back 77,000 Vietnamese", SCMP 1 Mar. 1990.

44. See, for example, statements by Legislative Councillors, LegCo Proc 19 Nov. 1989 at p.441 ("we are stretched to our limits"), p. 445 ("it is impossible for Hong Kong to look after the Vietnamese refugees and boat people perpetually and take them indefinitely as they come in ever increasing numbers"), p.457 ("our society has been hard-pressed to the end of its tether"), p.458 ("Hong Kong is at the end of its tether in dealing with the Vietnamese boat people"), p.465 ("given our limited land resources, we are really unable to accomodate the endless influx of Vietnamese boat people"), p.474 ("with the scarcity of land, manpower and funds, the situation has become increasingly unbearable that we can hardly stand the continued presence of the boat people in the territory"), p.476 ("the Vietnamese boat people problem is becoming intolerable to Hong Kong both in terms of the material burden placed on us and the mental stress caused to the citizens at large").

45. D.PERLUSS \& J.F.HARTMANN, "Temporary refuge: emergenceof a customary norm", 26 Va JIL, p.551, $621-2$.

46. Art. 33(2): "The benefit of the present provision may not, however, be claimed by a refugee whom there are reasonable grounds for regarding as a danger to the security of the country in which he is, or who having been convicted by a final judgment of a particularly serious crime, constitutes a danger to the community of that country."

47. GA Res.2312 (XXII) of 14 Dec. 1967, UN GAOR, 22nd Sess., Supp.No 16, p.81.

48. Article 3(2). 
quently subject to self-serving definition. ${ }^{.49}$ Yet, as an exception to a fundamental principle it must be interpreted restrictively. Clearly, not all unilateral determinations of threats to national security are acceptable to other States or tolerated by them. Thus Malaysia's rejection of boat people in 1978 for fears of "upsetting delicate racial balance ${ }^{m 50}$ and Thailand's "push-back" policy against Kampuchean refugees in early 1979 motivated by a perceived need to control "resentment among indigenous people ${ }^{n 51}$ have provoked vigorous international protests. A fortiori, general claims of "exhaustion" and "resources drainage demands for international assistance ${ }^{53}$ - could not justify derogations from what is widely recognised as a fundamental (even "peremptory ${ }^{n 54}$ ) norm of international law.

A "balancing of interests" approach, suggested by a learned author, 55 holds considerable attraction and is consistent with general principles of international law. According to Feliciano, "the first step is to recognize that both the humanitarian claims of refuge-seekers and the claims of States to authority to protect their security interests are legitimate claims. There is no need to pretend that legitimate State interests are not engaged by the presence of refugees insistently knocking at the frontier, as it were. Neither can it be reasonably supposed that State interests must simply and always override claims made in the name of humanity. ${ }^{56}$ The universally recognised principles of necessity and proportionality offer a conceptual vehicle for the reconciliation of conflicting interests. Thus "humanitarian claims for refugees may be denied and refoulement resorted to only when such measure has become indispensably necessary for the protection of an equally weighty State interest. ${ }^{57}$ In a similar vein, "the human suffering imposed by refoulement must not be grossly disproportionate to the substantive value of the State interest sought to be maintained. ${ }^{n 58}$

49. PerLuss \& Hartman, supra n.45, at p.621.

50. See XXVI Keesing's Contemporary Archives, Cols.30076, 30077, 30079 (1980).

51. See K.SOBHAD-VICHITR, "The Indochinese refugee problems: viewpoint from Thailand", in Asian Experts Report 1980, supra n.21, at p. 176.

52. Of the type raised by LegCo members, supra n.44.

53. See TertelBaum, "Immigration, refugees and foreign policy", 38 Int'l Org. (1980), p.429, 436.

54. See Report on the Meeting of the Expert Group on Temporary Refuge in situations of LargeScale Influx, EC/SCP/16, 3 June 1981, at p.6; EXCOM, Note on International Protection, A/AC.96/ 660, 23 July 1985, at p.5; EXCOM, Note on Internatinal Protection, A/AC.96/694, 3 Aug. 1987, at p.7.

55. See P.F.Feliciano, "The principle of non-refoulement. A note on international legal protection of refugees and displaced persons", 57 Phil.L.J., p. 598.

56. Ibid, at p.606.

57. Loc.cit. 
Applying these principles in the Hong Kong context, it is apparent that the refugees have not posed a tangible threat to the territory's security. Their presence has not jeopardised Hong Kong's relationships with other parties, has not caused a sharp deterioration in public order and has not imposed an intolerable burden on the treasury and the community at large. On the other hand, the harm inflicted on asylum seekers if the principle of non-refoulement were to jettisoned would be substantial.

Nor can an argument be made that "since the resettlement countries have failed to fulfill their commitment which is crucial to the operation of first asylum policy, Hong Kong should no longer be obliged to take up the responsibility as a port of first asylum. ${ }^{n 59}$ In accordance with a well-established rule of international law, ${ }^{60}$ Hong Kong's unilateral declaration in 1979 - make publicly, in respect of a legal/factual situation and with intent to be bound - has had the effect of creating a legal obligation for the Government to follow a course of conduct consistent with the declaration independent of any quid pro quo. Thus unfulfilled expectations do not furnish a legal ground for non-compliance. Similarly, although representatives of first asylum countries at the 1989 Geneva Conference expressed their desire and hope that asylum seekers would eventually either be resettled outside the region or return to their countries of origin, the obligation to provide temporary refuge is unconditional and legally binding. ${ }^{61}$

Admittedly, "international solidarity and equitable burden-sharing" are generally considered as principles of international refugee $\operatorname{law}^{62}$ and as "indispensable for satisfactorily resolving problems of refugees and displaced persons arising in situations of large-scale influx ${ }^{763}$ but they "should not be a precondition for compliance with basic humanitarian principles. ${ }^{n 64}$ As elaborated by a UNHCR representative, "[i]t is axiomatic that asylum seekers should not be rejected at a frontier or expelled if this would oblige them to return or to remain in a country where their life or freedom would be threatened. Equally, asylum seekers should not be refused temporary asylum if this would involve their returning to the high

58. Loc.cit.

59. LegCo Proc., 19 Nov. 1989 , at p.447.

60. See Nuclear Tests Case (Australia v. France, [1974] ICJ Rep., at pp.253, 267-70.

61. See Perluss \& HaRTMann, supra n.45, at p.616, for the view that temporary refugee consitutes an obligation erga omnes, independent of finding the responsibility by another party and not contingent on reciprocity or burden-sharing arrangements.

62. See G.ColEs, "Problems at the large-scale influx" in Report of Asian Experts 1980, supra n.21, at pp.35, 42,44 .

63. Manila Declaration on the International Protection of Refugees and Protected Persons in Asia, repr. in EXCOM, Note on the Round Table of Asian Experts on International Protection of Refugees and Displaced Persons, UN Doc. A/AC.96/INF. 162 Annex I (1980), para 10.

64. Loc. cit. 
seas where their very lives may be in danger. The observance of these principles should not vary according to the extent to which the burdensharing arrangements are at any given moment considered to be adequate. ${ }^{65}$

Finally, the norms of non-refoulement and temporary refuge are grounded in the acceptance by the international community that the basic principles of humanity, protection of life and dignity must be granted to persons who have lost their national protection. These humanitarian-inspired duties are imposed regardless of the sovereign or otherwise status of the territory where asylum is sought. Thus Hong Kong's transition from British to Chinese rule in 1997 should not affect its compliance with international obligations under international refugee law. ${ }^{66}$

\section{DETERMINATION OF REFUGEE STATUS}

\subsection{The Screening Process}

\subsubsection{International Rules}

While defining the obligations of the parties towards refugees, the 1951 Refugee Convention and its 1967 Protocol are silent on the issue of method for determining who is a refugee entitled to protection. "It is therefore left to each Contracting Party to establish the procedure that it considers most appropriate, having regard to its particular constitutional and administrative structure. ${ }^{n 67}$

Yet, by virtue of a Grundnorm of international law, the principle of pacta sunt servanda, 68 "states ratifying the 1951 Convention and the 1967 Protocol necessarily undertake to implement these instruments effectively and in good faith." 69 "While the choice of means may be left to states some such procedure [for identifying those who are to benefit] would seem es-

65. P.M.MousSALL, "Fundamental principles in the international protection of refugees and displaced persons", Report of Asian Experts 1980, supra n.21, at p.14.

66. Indeed, the territory's responsibility may derive an additional legal force should the PRC extend to the Hong Kong Special Administrative Region (HKSAR) the Refugee Convention to which it is a party (supra, n.19).

67. Office of the UNHCR, Handbook on Procedures and Criteria for Determining Refugee Status (Geneva, Sept. 1979) [Hereafter: UNHCR Handbook], para. 189.

68. The principle is expressed in Art. 26 of the 1969 Vienna Convention on the Law of Treaties, as follows: "Every treaty in force is binding upon the parties to it and must be performed by them in good faith." UN Doc A/CONF. 39/27 (1969).

69. Good-GiLL, supra n.4, at p.147. 
sential for the effective implementation and fulfillment of convention obligations. ${ }^{70}$

It is equally clear that observance of the fundamental principle of nonrefoulement (and its "temporary refuge" corollary) hinges on the institution of appropriate determination procedures. Indeed, according to one expert, if we wish to attach any meaning to the principle of non-refoulement we have to assume that "a person claiming to be refugee has a right to have his claim examined. ${ }^{n 11}$

The pivotal aspect of the refugee status determination process has also been recognised at the 1989 Geneva Conference on Indo-Chinese Refugees which posited as part of a Comprehensive Plan of Action (CPA) ${ }^{72}$ the requirement that such a process be established and "take place in accordance with national legislation and internationally accepted practice." [Section D6]

Specifically, the CPA stipulates [para. (d)] that "the procedures to be followed will be in accordance with those endorsed by the Executive Committee of the Programme of the UNHCR in this area. Such procedures will include inter alia: (i) the provision of information to the asylum-seekers about procedures, the criteria and the presentation of their cases; (ii) prompt advice of the decision in writing within a prescribed period; (iii) a right of appeal against negative decisions and proper appeals procedures for this purpose, based upon existing laws and procedures of the individual place of asylum, with the asylum-seekers entitled to advice, if required, to be provided under UNHCR auspices."

Basic to the procedural standards thus reaffirmed is the notion of due process and the international recognition of the special need and vulnerability of asylum-seekers - a concern duly reflected in the preliminary requirement that status determination be carried out by "qualified personnel having the necessary knowledge and experience and an understanding of an applicant's particular difficulties and needs. ${ }^{73}$

\subsubsection{The British Position}

No formal refugee determination procedure is incorporated in UK law (although an informal administrative process is said to have been developed by the Home Office ${ }^{74}$ ), rendering it somewhat "difficult... to hold au-

70. Ibid at p.148.

71. A.GRAHL-MADSEN, "Refugees and refugee law in a world of transition", 19 AWR Bulletin (1981), at p.95.

72. Repr. in 1 IJRL (1989), at p.574.

73. UNHCR Handbook, para. 190. 
thorities accountable for alleged procedural malfeasance or mistaken determinations. ${ }^{\text {"75 }}$

Yet, British judges have not hesitated to review the Executive's decisions concerning asylum-seekers and uphold procedural standards, recognising that serious issues of life and liberty are inherent in refugee claims. As stated by Lord Bridge - in an oft-quoted passage from his speech - in the House of Lords Decision $R v$. Secretary for the Home Department, ex parte Bugdaycan \& Others and In re Musisi ${ }^{76}$ "[t]he most fundamental of all human rights is the individual's right to life and when an administrative decision under challenge is said to be one which may put the applicant's life at risk, the basis of the decision must sure call for the most anxious scrutiny." The same notion was echoed in Lord Templemen's speech: "In my opinion where the result of a flawed decision may imperil life or liberty a special responsibility lies on the court in the examination of the decision-making process. ${ }^{n 7}$

While not regarding themselves as bound by EXCOM's recommendations with respect to the determination process ${ }^{78}$, British judges have nonetheless applied the principle of "fairness" to develop procedural guarantees consistent with the recommendations. Specifically, the courts held that the procedure adopted by the immigration authorities be revised to provide applicants with copies of the completed asylum questionnaires (each page of which has been read over to and initialed by the applicant), including the immigration officers' comments; ${ }^{79}$ that an applicant be provided with the opportunity "to consider calmly whether there is anything which he should add or alter" and that he be reminded of previous answers and directed to considerations which are likely to defeat his/her application; ${ }^{80}$ that individuals be allowed to address discrepancies and issues of credibility; ${ }^{81}$ and that full reasons be given for refusal of asylum. ${ }^{82}$. Of particular importance is the House of Lords' decision which confirmed that the civil burden of balance of probability is not appropriate in asylum cases. As held in $R$. $v$. Secretary of State for the Home Department

74. See C.L.AVERY, "Refugee status decision-making: the systems of ten countries", 19 Stan JIL (1983), at pp.235, 319 .

75. Ibid., at p.326.

76. [1976] AC 514 at p.531.

77. Ibid., at p.537.

78. Note that the UK is a member of EXCOM.

79. R. v. Secretary of State for the Home Department ex parte Thirukumar and Others, [1989] 1 Imm.A.R.270.

80. Loc. cit.

81. R. v. Secretary of State for the Home Department ex parte Gaima, [1989] 2 Imm.A.R.205.

82. R. $v$. Secretary for the Home Department ex parte Gurmeet Singh and Others, [1987] 4 Imm. A.R.489. 
ex parte Sivakumaran ${ }^{83}$, asylum-seekers need only show a "reasonable likelihood" that they will face persecution for a "convention reason" to be recognised as refugees.

It may be concluded that, although the British status determination systems falls short of meeting all recommended standards of practice ${ }^{84}$, administrative checks ${ }^{85}$, judicial safeguards, and to a certain extent political control mechanisms ${ }^{86}$ have served as a counterbalance to some of the deficiencies.

\subsubsection{Regional Attitudes}

Centralised ${ }^{87}$ refugee status determination procedures have only been formally established in the region following the adoption of the CPA in June 1989 by the International Conference on Indo-Chinese Refugees.

In an attempt at uniformity and harmonisation, a Co-ordinating Committee for the International Conference on Indo-Chinese Refugees drew up the procedures it envisaged for the region's countries of first asylum following discussions with the respective governments. ${ }^{88}$ A comprehensive regional training programme for officials involved in the determination process was also instituted by the UNHCR "with a view to ensuring the proper and consistent functioning of the procedures. ${ }^{n} 89$

Generally, the regional parties to the CPA have undertaken to follow

83. [1982] 2 WLR 92.

84. See criticisms by AVERY of the following aspects: "...process largely controlled by immigration authorities, whose overall responsibility to 'control the borders' may condition them to be enforcement-minded and skeptical rather than impartial and sensitive to the special problems of refugees. Accurate decision making is further jeopardised by the fact that determinations at the Refugee Unit [Immigration \& Nationality Department, Home Office] are based on a transcript prepared by a non-specialised officer, without the benefit of a personal appearance by the applicant before the decision-maker and usually without the benefit of UNHCR input... Furthermore, the review process is unsatisfactory. The most serious problem at that stage is that right to appeal is effectively denied to certain applicants because of their immigration status at the time of application." Supra n.74 at p.326. See also RuFF, supra n.17 for a discussion of the need for reform and in particular the establishment of a right of appeal for refugees whose application for asylum has been rejected.

85. Such as review by the Head of the Refugee Unit of all negative refugee determinations made by a unit officer, review by a UNHCR representative of every case including poissible intervention on behalf of the refugee at the appellate level. See AVERY, supra n.74 at p.325.

86. By informal but longstanding practice, asylum and refugee status cases may be revewed at the ministerial level of the Home Office when a Member of Parliament intervenes on behalf of the applicant. See AVERY, ibid.. at p.324-5; RUFF, supra n.17 at p.489.

87. A limited programme was introduced in Thailand on 1 July 1985. Designed to screen Laotian asylum-seekers, it provided an "uneven" accesss to highland and lowland Lao and was applied inconsistently by the various Thai provinces. See World Refugee Report, supran.23 at p.33-4.

88. See Note on National procedures for the Determination of Refugee Status (Geneva, 23 \& 26 May 19899 [hereafter: Note on Procedures].

89. CPA, supra n.72, Sec.D7. 
the procedures endorsed by EXCOM. Yet, it appears that the regional screening mechanisms - installed largely as added deterrents - are outcome-oriented and do not adequately reflect the vulnerable position of refugees within an alien system. In particular, little or no pre-screening advice and assistance in presentation of cases are given to asylum seekers. Nor is a right to appeal or to court review firmly guaranteed. ${ }^{90}$ It is also evident that while some form of UNHCR participation ("observer/adviser") is provided for, governmental control is ensured at all stages of the screening process. ${ }^{91}$

\subsubsection{The Hong Kong Approach}

Hong Kong has played a pioneering role in attempts to institute refugee status determination procedures in the region. Under a policy announced by the Government, as of 16 June 1988, all arrivals from Vietnam were to be treated as "illegal immigrants" ${ }^{\mathrm{92}}$ unless determined by a screening process to be refugees in accordance with the definition embodied in the 1951 Convention and its 1967 Protocol.

Although no specific legislation was adopted to reflect this shift in policy $^{93}$, in a Statement of Understanding concluded with the UNHCR on 20 September 1988, the Hong Kong Government has confirmed "its commitment to the establishment and operation of procedures for determination of refugee status which are in accordance with the UNHCR Handbook". Hong Kong authorities have further endorsed a revised ${ }^{94}$ procedure for

90. Based on information contained in the Note on Procedures, in Indonesia, an applicant who wishes to appeal must seek leave from an Appeal Board within a prescribed period. The Board will grant leave to appeal on the basis of the information provided, if it appears that there are new facts or that the criteria or procedures may have been misapplied. In Malaysia, applicants are informed of the "possibility" of having a negative decision reviewed and are required to submit a notice of intention and grounds for review within a prescribed period. In Thailand, the UNHCR is entitled to institute an appeal on behalf of a rejected case. Only in the Philippines does appeal seem automatic.

91. Indonesia's "screening commission" is led by an immigration officer and includes officials from P3V (the national body responsible for Vietnamese refugees); the appeal board is similarly constituted. In Malaysia, determination decisions are made by immigration officials attached to the National Task Force VII; review of negative decisions is also undertaken by officials of the National Task Force. Determination of refugee status in the Philippines is made by a CID (Commission on Immigration and Deportation) Officer but appeals will be submitted to the Inter-Agency Task Force on International Refugee Assistance and Administration. The Board of Status Determination in Thailand is chaired by an official of the Ministry of the Interior. Review of decisions is carried out by the same board consisting of more senior officials. 92. Note, however, that as a result of UNHCR's intervention, previous "warning notes" issued to arrivals upon entering Hong Kong's harbour have been revised to indicate that former residents of Vietnam are treated as asylum-seekers (not illegal immigrants) pending determination of their status. See Security Branch, "Notice of Arrival".

93. Before 16 June 1988 all Vietnamese arriving in Hong Kong were automatically deemed to be refugees.

94. See Note of Procedures, supra n.88. 
status determination of Vietnamese asylum-seekers introduced on 1 July 1989 subsequent to the Geneva conference on Indo-Chinese Refugees. In particular, a Refugee Status Review Board (RSRB) was set up ${ }^{95}$ to act on behalf of the Governor in council in considering applicants for review of negative determination decisions.

Further modifications were announced by the Government in February 1990 - in an attempt to address criticisms expressed by various bodies (UNHCR, Amnesty International, Indochina Resource Action Centre, Lawyers Committee for Human Rights, World's Commission for Refugee Women and Children) - including more training for interpreters and the granting to asylum seekers of access to written records of interviews with immigration officers before a decision is made on their status. ${ }^{96}$ In addition, as part of what it regards as "a process of fine tuning", the Government "agreed" in April 1990 that RSRB should give reasons for adverse decisions. ${ }^{97}$

\subsubsection{Assessment}

Notwithstanding improvements in status determination procedures, the screening process in Hong Kong remains flawed and does not fully accord with the basic requirements for a fair and effective determination system which underlie compliance in "good faith" with international refugee norms.

Specifically, concerns persist in relation to the lack of legal advice and assistance to individual asylum-seekers at all stages of the screening process; ${ }^{98}$ the attitude and competence of immigration officers (superficial approach, lack of familiarity with international refugee law and conditions in Vietnam); ${ }^{99}$ the competence of interpreters; ${ }^{100}$ and the shortcomings in the review procedure (in particular the fact that neither asylum-seekers nor their representatives are allowed to be present). ${ }^{101}$

In fact, not only are international standards disregarded, but Hong Kong's screening process fails to conform to general principles of natural

95. See Immigration (Refugee Status Review Boards) (Procedure) Regulations 1989, L.N. 170/ 89 L.S.No. 2 to Gazette No. 24/1989.

96. See K.Griffin, "Government Backdown on Screening”, SCMP 25 Feb. 1990.

97. F.MACMAHON, "Board to Give Reasons for Viet Refusal", SCMP 27 Apr. 1990.

98. See Amnesty International Memorandum to the Government of Hong Kong and the United Kingdom Regarding the Protection of Vietnamese Asylum-Seekers in Hong Kong (January 1990) [hereafter: Amnesty Memorandum] at p.14.

99. Ibid., at pp.18-22.

100. Ibid., at p.23.

101. Ibid., at pp.24-5. 
justice which form part of the territory's own legal system. Critics draw particular attention to the fact that applicants, who are not given proper or adequate notice of the hearing/interview or its importance, are denied the right to fair hearing ${ }^{102}$; that the interview conducted by the Immigration Officers is superficial, perfunctory and rushed; that the interpreters are insufficiently skilled, knowledgeable and articulate to fully and properly interpret applicants' answers, the immigration officers' questions and to permit applicants to fully state their case; that the applicants are not permitted to have legal or other advisers of their choice present throughout the interviews; that the applicants' answers are improperly recorded and as recorded by the immigration officers are misleading in fact, significance and context; that the interview records are never shown to the applicants nor are answers purportedly given by applicants read back to them so that the applicants could add or alter them; that the applicants are not given reasons or sufficient and proper reasons for the rejection by the immigration officers of their claim to refugee status, a factor also hindering proper preparation for appeal; that applicants are not provided with the opportunity to consider and if necessary provide further evidence about any provisional findings or reasons adverse to the applicants' claim for refugee status prior to a formal decision adverse to the applicants being made. ${ }^{103}$

Some external "safety-nets" are available such as UNHCR monitoring of interviews ${ }^{104}$, post-determination representation (preparation of written submission for consideration by RSRB) by AVS (Agency for Voluntary Service) lawyers ${ }^{105}$, and the UN mandate system (which allows asylum-seekers in special cases to qualify as refugees despite their failure to gain recognition in the screening process). However, they are not adequate to compensating for the defects in the screening process and, as stressed by Amnesty International, "it is governments that are responsible for ensuring proper, fair and just refugee determination procedures. ${ }^{106}$

102. Contrary to, e.g., Kanda v. Government of Malaya [1962] AC 322 at p.337.

103. See D.Clark, A.JoRdAn, C.PETERSEN and H.SAmuels, The Flaws in the Vietnamese Refugee Screening Process in Hong Kong (18 June 1990, unpublished) [hereafter: Lawyers Report]; see also, application for judicial review submitted to the High Court seeking to quash by certiorari adverse refugee determinations: In the Matter of Nguen Ho \& Others and the Director of Immigration and Refugee Status Review Board (not yet heard).

104. Because of limited resources only a very small proportion of screening interviews are in fact monitored; there are only $3-4$ UN lawyers to monitor 80 screenings taking place at any one time.

105. Again, for limited resources - only 10 lawyers - AVS legal advisers can actually take up and act on behalf of $10 \%$ of the cases they see.

106. Amnesty Memorandum, supra n.98, at summary 2. 


\subsection{Substantive Criteria}

\subsubsection{International Rules}

While a definition of "refugee" is not universally agreed upon, the criteria incorporated in the 1951 Refugee Convention and its 1967 Protocol have been generally recognised as the basis of status determination procedures by many States, including non-parties. Decision-makers have also referred occasionally to the UNHCR Handbook as an authoritative source in interpreting relevant criteria, although the Convention's imprecise language (in particular the absence of a definition of "persecution") made way for States' own selective interpretation and restrictive application.

Basically, the key criterion in establishing refugee status under the Refugee Convention is a "well-founded fear of being persecuted." Persecution, however, has not been defined in any of the major international instruments concerning refugees, resulting in considerable divergencies in approaches. As one commentator observes, while a threat to life or freedom on one of the five cognizable grounds listed in the Convention will always constitute persecution, extending the concept beyond these parameters is a policy exercise whose outcome hinges on whether one takes a conservative or liberal approach. ${ }^{107}$

Arguably, a liberal approach is more consistent with both the spirit and practice of international refugee law. Thus, true to its ostensibly humanitarian objective and spirit, the Refugee Convention sets out to locate the refugee in a human rights framework by highlighting in the first paragraph of its Preamble the basic principle affirmed in the 1948 Universal Declaration of Human Rights, namely that human beings shall enjoy fundamental rights and freedoms without discrimination. A definition of "persecution" which includes serious ${ }^{108}$ violations of human rights or discrimination (for cognizable grounds) is clearly consonant with such a principle. It is further argued ${ }^{109}$ that a human rights orientation is implied in the "letter" of the Convention. An illustration is afforded by Art. 33(1) which speaks of threats to life and freedom and hence invites a broader interpretation of the notion of "persecution" which is not merely equated with deprivation of life or attacks on physical integrity.

That a humanitarian - as distinct from legalistic - attitude should be

107. See P.HYNDMAN, "The 1951 Convention definition of Refugee: An appraisal with particular reference to the case of Sri Lankan Tamil applicants", 9 HRQ (1987), at pp.49, 60.

108. "...a degree considered unacceptable under prevailing international standards or under higher standards prevailing in the State faced with determining a claim to asylum or refugee status". See GOODWIN-GILL, supra n.4 at p.43.

109. See B.M. Tsamenyl, "The 'Boat People': Are they refugees?", 5 HRQ (1983), at pp.348, 364. 
adopted is moreover evinced in a recommendation by the drafters of the Refugee Convention who urged States to apply the Convention beyond its strictly contractual scope to other refugees within their territory. 110

Indeed, the main situation charged with protection of refugees, the UN$\mathrm{HCR}$, has not confined itself to the legal definition of refugee and its criterion of "well-founded fear of persecution." Instead, its mandate has expanded to include "displaced persons" ${ }^{n 11}$ and it has adopted much looser working categories which encompass persons who are unable to meet the technical requirements stipulated under the Convention. ${ }^{112}$

Support for the liberal approach to the interpretation of "persecution" may also be adduced from the practice of States. As documented by one author, "Australia, for example, has a declared policy of resettling 'people in refugee-type situations which do not fall within the UNHCR mandate or within Convention definitions.' Italy guarantees a right of asylum to aliens who are denied the practical exercise of freedoms guaranteed by the Italian Constitution... Great Britain grants asylum to 'a sizable number' of persons who do not qualify under the international definition... ${ }^{n 113}$ In the Netherlands, the law provides that persecution entails a contravention of basic rights and refers in this context to the European convention on $\mathrm{Hu}-$ man Rights. ${ }^{114}$ On a regional level, the Committee of Ministers of the Council of Europe issued a declaration calling for the recognition of asylum rights for all persons coming within the Convention's definition of refugee and to other persons whom member States "consider worthy of receiving asylum for humanitarian reasons. ${ }^{.115}$ In Africa, the Organisation of African Unity has formally expanded the definition of refugee to include also persons outside their countries of origin "owing to external aggression, occupation, foreign domination or events seriously disturbing public order. ${ }^{116}$

Agreement on a liberal interpretation of "persecution" will not, however, eliminate other ambiguities concerning the criteria for determining refugee status, such as the standards of evaluating the fear of persecution, the scope of recognised grounds of persecution, and the agents of perse-

110. Conference of Plenipotentiaries, Final Act, Recommendation E, cited in GoodwiN-GILL, supra n. 4 at p. 13 n. 48 .

111. See 34 UN GAOR Supp. No.46 (UN Doc. A/Res/34/60) at p.173 (1979).

112. See MAYNARD, "The legal competence of the UNHCR", 31 ICLO (1982) 415, 416-20 for a discussion of so-called "statutory", "protocol" and "mandate" refugees.

113. See D.P. GAGLIARDI, "The inadequacy of cognizable grounds of persecution as a criterion for according refugee status", 24 Stan JIL (1987), at pp.259, $262-3$.

114. See R.Plender, International Migration Law, 2nd edn., (Martinus Nijhoff, 1987) at p.418 n.185.

115. Cited in GAGLJARDI, supra n.113 at p.262.

116. OAU Convention Governing the Spacific Aspects of Refugee Problems in Africa, 1974, 691 UNTS 14. 
cution.

Again, approaches vary but certain general propositions are said to be reflected in the "best state practice" to be emulated by other States as representing the true letter and spirit of the refugee Convention. ${ }^{117}$ Thus, with respect to the standard of fear, the UNHCR offers a modus vivendi involving an assessment of the applicant's subjective fear (which in turn requires both an examination of the applicant's past experiences and background as well as his future prospects if returned to his or her country of origin) ${ }^{118}$ as "supported by an objective situation." 119 The objective element, however, does not necessitate an exacting burden of proof ${ }^{120}$ and the examiner should assist the applicant in developing his supporting evidence. ${ }^{121}$ Finally, "if an applicant's account appears credible, he should, unless there are good reasons to the contrary, be given the benefit of the doubt." 122

The UNHCR Handbook also provides guidelines concerning the five reasons of persecution specified in the Refugee Convention (i.e. race, religion, nationality, membership of a particular social group, or political opinion). ${ }^{123}$ Of particular note are the statements pertaining to "race" which is to be understood in its widest sense, to include all kinds of ethnic groups - "nationality" - also to be interpreted broadly to cover citizenship as well as membership of specific ethnic or linguistic groups - and "membership of a social group" - which frequently overlaps with the other categories as it pertains to persons sharing similar background, habits, economic activities or social status as well as ethnic, cultural or linguistic origin. 124

Further counsel is to be drawn from the various international instruments relating to human rights. Such instruments are useful, for instance, in the elaboration of the ground of "religion"125 as encompassing membership of a religious community, personal faith, private worship or religious-

117. See discussion in T.N. Cox, "Well-founded fear of being persecuted': the sources and application of a criterion of Refugee status", 10 Brooklyn JIL (1984) at p.333.

118. UNHCR Handbook, paras 40-1.

119. Ibid.para. 138.

120. Ibid.para. 197.

121. Ibid.para. 196.

122. Ibid.paras 196 , at pp.203-4.

123. Ibid.paras 66-86.

124. Little consideration has been given by officials to treating women as a particular social group. See, however, EXCOM's conclusion (1985) that women who face persecution for engaging in acts that would be tolerated in the case of men form a "social group" within the meaning of the Convention. See reference in PLENDER, supra n.114 at pp.422-3 n.221.

125. See Art.18, 1948 Universal Declaration of Human Rights; Art. 18, 1966 International Covenant on Civil and Political Rights; 1982 Declaration on the Elimination of all Forms of Intolerance and of Discrimination Based on Religion and Belief. 
ly motivated acts such as conscientious objection to military service.

International conventions and declarations should also be used as yardsticks for the interpretation of "political opinion." Understood in this context, "political opinion" refers to any opinion on a matter on which the machinery of the state, government and policy may be engaged. ${ }^{126}$ It is moreover not limited to active participation in groups, unions, demonstration, protests or to the persecution victim's conscious expression of conventional political belief. ${ }^{127}$ Given the difficulty in establishing a causal link between opinions expressed and related measures suffered, the detailed instructions provided in the UNHCR Handbook should be adhered to. ${ }^{128}$

As a general observation regarding grounds of persecution, although the Refugee Convention recognizes only five such grounds, the list need not be exhaustive. Indeed, in line with the liberal approach to persecution mandated by the Convention's humanitarian objective, it is difficult to disagree with the arguments put forward by one scholar that "cognizable grounds focus attention on the wrong question. Precisely why an individual is persecuted is largely irrelevant - the existence of persecution is the only essential question. ${ }^{129}$ As he further explains, "the categories are not sufficiently comprehensive to cover many of the grounds for which people are commonly persecuted. Second, since persecution need not, and frequently does not, have any articulable motivational basis, the mere existence of cognizable categories of persecution operates to restrict the common view of a refugee - a person fleeing what may reasonably be perceived as a threat of persecution. Reliance, therefore, upon cognizable categories of persecution will fail to provide relief to many aspiring refugees otherwise deserving of protection. ${ }^{n 130}$

Finally, another problematic aspect of persecution concerns the agents of persecution. Again, tendencies to confine the notion to the authorities of the country of origin have been pointed out. ${ }^{131}$ The UNHCR interpretation, however, merits support. That is " $[w]$ here serious discriminatory or other offensive acts are committed by the local populace, they can be considered as persecution if they are knowingly tolerated by the authorities, or if the authorities refuse, or prove unable to offer effective protected. ${ }^{n 132}$

126. See GoOdwiN-GlLL, supra n.4 at p.31.

127. UNHCR Handbook, paras 80,83 .

128. Ibid., paras $80-86$.

129. GAGLARDI, supra n.113 at p.272.

130. lbid., at p.273.

131. See E.FeLER, "Who is a Refugee?" in: Refugees in the World: The European Community's Response (Netherland's Institute of Human Rights, 1989) at 65.

132. UNHCR Handbook, para. 65. 


\subsubsection{The British Position}

The "well-founded fear" concept is incorporated in the British Immigration Rules in relation to both asylum and deportation procedures ${ }^{133}$ but no clear criteria are set out in the law for determination of an asylum-seeker as a "refugee."

Administratively, it is contended that the Home Office's interpretation of "well-founded fear" "is carried out in the light of the advice given in the [UNHCR] Handbook. ${ }^{n 134}$ However, as transpired in the case of Sivakumaran and Others ${ }^{135}$, the Secretary of State for the Home Department had interpreted the phrase "well-founded fear" as meaning that the applicant was required to establish not only that he in fact feared persecution on one of the specified grounds but also that those fears were objectively justified. Presumably, the Home Office will now follow the House of Lords' ruling and act upon the test of a "reasonable degree of likelihood" of persecution for Convention reason if the applicant returned to his/her own country. 136

Yet, the Home Office appears to have the judiciary's qualified support for the proposition that refugee status was not intended to be conferred on those who faced persecution by reason of events which lay in the future and that therefore a person could not claim protection on the ground that if he/she were returned to the foreign state his/her freedom to express political views would be restricted. As held by the Court of Appeals in ex parte mendis $^{137}$, a person was not at risk of being persecuted for his political

133. Supra n.13. Para. 134 provides: "A person may apply for asylum in the United Kingdom on the ground that, if he were required to leave, he would have to go to a country to which he is unwilling to go owing to well-founded fear of being persecuted for reasons of race, religion, nationality, membership of a particular group or political opinion. Any such claim is to be carefully considered in the light of all relevant circumstances." Para. 165 provides: "In accordance with the provisions of the Convention and Protocol relating to the Status of Refugees, a deportation order will not be made against a person if the only country to which he can be removed is one to which he is unwilling to go owing to well-founded fear of being persecuted for reasons of race, religion, nationality, membership of a particular group or political opinion."

134. Based on an interview cited in Cox, supra n.117 at 361 .

135. Supra n.83.

136. The House of Lords did not accept, however, the approach favoured by the Court of Appeal that "well-founded fear" was demonstrated by proving actual fear and good reason for that fear, looking at the situation from the point of view of one of reasonable courage in like circumstances as the applicant for refugee status. [1987] 3 WLR 1047,1053. Nor did the House of Lords agree with the interpretation put forward by a UNHCR representative that "wellfounded fear" meant fearing with "good reason", i.e., that on the basis of objective facts, the applicant's fear was reasonable and plausible. [1988] 2 WLR 92, at pp.102-4.

137. The Times Law Reports, 18 June 1988. 
opinions if no events which would attract such persecution had yet taken place. $^{138}$

Nor have British courts questioned the Home Office's restrictive approach to the meaning of persecution in requesting applicants to show that they have been personally "singled out for persecution" ${ }^{\text {139 }}$, although a divisional judge considered as "false" an apparent presumption by the Home Office that violence to individuals flowing from a conflict between factions cannot amount to persecution (the implication of which was that oppression or violence to a racial minority would only be persecution if conducted by the authorities). ${ }^{140}$

To a certain extent, British decision-makers are constrained by the European convention on Human Rights to which the UK is a party. However, attempts to challenge judicially the Home Secretary for failing to take into account provisions of the Convention have been unsuccessful. The courts reaffirmed the position that "the Convention, not having been enacted by Parliament as a statute, it does not have the effect of law in this country, whatever persuasive force it may have in resolving ambiguities it certainly cannot have the effect of overriding the plain provisions of the [immigration] Act of 1971 and the rules made thereunder. ${ }^{1141}$ Furthermore, notwithstanding the ratification of the treaty by the UK Government, no legitimate expectations arise that the Secretary of State will take its provisions into account as part of the "relevant circumstances." 142

Despite administrative and interpretive strictures that exist in British refugee status decision-making, a considerable number of persons who did not meet the formal criteria under the Refugee Convention have nonetheless been allowed to remain in the UK exceptionally "because of the

138. The Court (per Lord Justice NEIL) was "unable to agree with the view" put forward in the UNHCR Handbook (para. 82) that where it could be reasonably assumed that a person's opinions would sooner or later find expression and that the applicant would as a result come into conflict with the authorities she/he could be considered to have fear of persecution for reasons of political opinion. A somewhat modified approach was presented by Lord Justice STAUGHTON who maintained that "[i]f a person had such strong convictions, whether on religious or other grounds, that he would inevitably speak out against the regime in his country of origin, and would inevitably suffer persecution in consequence, it might be that he should be treated as a refugee."

139. See Ex parte Gurmeet Singh \& Others [1987] 4 Imm. AR 489. Lord Justice Woolf accepted as relevant in a case of a Sikh's application for asylum a "singling out" requirement. In contrast, see decisions by the Australian Federal Court in Periaman $v$. Minister for Immigration \& Ethnic Affairs (1987) and Gunaleela v. Minister for Immigration \& Ethnic Affairs (1987), cited and discussed in J.CRAWFORD \& P.HYNDMAN, "Three heresies in the application of the Refugee Convention", I IJRL (1989), p.155 at pp.159-167.

140. Per TAYLOR J. in ex parte Juiakumaran (1985), referred to in ex parte Gurmeet, supra n.139. 141. Ex parte Salamat Bibi, [1976] 1 WLR 979, 988A (per GeOFFrEY LANE L.J.); See also Fernandes $v$. Secretary of State for the Home Department, [1981] 1 Imm. AR 1,5 (per WALTER L.J.). 142. Chundawadra $v$. Immigration Appeal Tribunal, [1988] 1 Imm. AR 161, 174 (per GLIDEwELL L.J.), 174-5 (per CAUlfield J.), 176 (per Slade L.J.). 
particular circumstances of their case or in the light of the situation prevailing in their home country." As declared by the Parliamentary UnderSecretary of State for the Armed Forces, Lord Trefgarne, in the course of a debate on the subject of refugees in the Third World, "the situation in some countries has caused us to establish several exceptional policies for certain nationals. In recent years the countries concerned have included Afghanistan, Iran, Lebanon, Poland and Uganda. Under these policies less stringent tests than the criteria for refugees are applied in deciding whether a person should be allowed to remain here exceptionally. ${ }^{143}$

Be that as it may, like the criteria for asylum, the exceptions for allowing "non-convention" refugees to remain in the UK have not been formally codified. It has consequently been alleged that many refugee decisions by the British authorities are politically influenced ${ }^{144}$, particularly since the Home Office relies heavily on information provided by the Foreign Office. ${ }^{145}$

\subsubsection{Regional Attitudes}

Prior to the adoption of the CPA in June 1989 and the introduction of formal refugee status determination procedures, the regional attitudes to "who is a refugee" might have been described as flexible. Classification of asylum-seekers varied with circumstances and terms such as "illegal entrant/migrant", "displaced person" and "refugee" were often used interchangeably. ${ }^{146}$

Indeed, to a large extent, the region's problem of "long-stayers"147 is the result of the "indiscriminate" approach displayed by the countries in the region in extending temporary refuge to [all] Indo-Chinese arrivals, a considerable portion of whom were not able to meet the selective criteria applied by resettlement countries.

On the other hand, regional attempts at distinguishing "genuine refugees" when geared to resettlement, inevitably incorporated irrelevant considerations. ${ }^{148}$

While precise definitions of "refugee" are been discounted by scholars and human rights lawyers in favour of inquiries into "whether protection

143. Cited in 56 British Yearbook of International Law (1985) at p.422.

144. Howl.AND, supra n.18 at p.60.

145. Ibid. at p.59.

146. See MUNTARBHORN, supra n.21 at pp.167-8.

147. Refugees who resided in a first-asylum camp for three years or more.

148. As illustrated in Thailand's screening of Laotian asylum-seekers. See V.MUNTARBHORN, "Trends and developments in durable solutions for refugees", in Yearbook 1986-87 International Institute of Humanitarian Law, (San Remo, 1989) at p.185. 
is needed ${ }^{\text {149 }}$ the region's nations appear content to apply the "tradition$\mathrm{al}^{\text {" }}$ criteria embedded in the 1951 Refugee Convention and its Protocol in their newly instituted status determination procedures. ${ }^{150}$ Since no information is yet available on regional attitudes as reflected in the application of the criteria, it may be assumed that UNHCR's proposed involvement in the screening process would contribute towards alleviating fears that form will be raised over substance, class over need and characterisation over purpose. ${ }^{151}$

\subsubsection{The Hong Kong Approach}

Under the Statement of Understanding reached between the Hong Kong Government and UNHCR concerning the Treatment of Asylum-Seekers Arriving from Vietnam in Hong Kong, "[ $t$ ]he Hong Kong Government confirms that appropriate humanitarian criteria for determining refugee status will be applied. These criteria, based on the UNHCR Handbook on Procedures and Criteria for Determining Refugee Status under the 1951 Convention and the 1967 Protocol, take into account the special situation of asylum-seekers from Vietnam." 152

Yet, it is difficult to assess Hong Kong's compliance with the international norms pertaining to refugee criteria since neither the immigration authorities - involved in the first stage of the determination process - nor the Refugee Status Review Boards - charged with reviewing negative determination decisions - have ever disclosed the criteria actually deployed or the burden of proof required to be discharged by applicants for refugee status.

Some evidence has nonetheless been adduced to the effect that whether due to a lack of familiarity with relevant international standards and human rights situation in Vietnam ${ }^{153}$ or because of attitudinal ${ }^{154}$, cul-

149. See G.GoodWIN-Glu. "Who is a Refugee?", in: Refugees in the World: The European Community's Response, supra n.131 at p.60.

150. See Note on Procedures, supra n.88.

151. GoodWIN-GlL, supra n.149 at p.60.

152. Supra, text at ns. 5-11.

153. It was noted that for a brief period after an intensive training session provided by the UNHCR to immigration officers involved in the screening process, "the rate of refugee recognition by immigration officers rose by a statistically significant amount. Shortly after, however, it fell to original levels." Amnesty Memorandum, supra n.98 at p.20.

154. Commenting on the low rate of "screening in" by the Director of Immigration, the Chairman of the Refugee Status Review Boards referred to the fact that the Director is "...a man of a 'discipline service'. A man who will be very very careful because of a very long rule not to exercise his discretion too widely because his livelihood depends on an exercise of discretion properly in the eyes of senior officers." Cited in Amnesty Memorandum, supra n.98 at p.21. 
tural $^{155}$ or other reasons ${ }^{156}$ - a restrictive approach, not consistent with a "humanitarian spirit" is adopted. Several cases have been cited of asylum-seekers who fell squarely within the Convention definition yet were "screened out" in the Hong Kong determination process. ${ }^{157}$

It is apparent that no broad "human rights inquiry" in any sort of depth is carried out nor is the likelihood and fear of human rights violations upon return to the country of origin thoroughly examined as an alternative basis for refugee status for those who do not meet narrow convention criteria. Indeed, the questionnaire currently used in the interview process is said to be deficient in this regard, particularly in view of the omission of questions relating to torture. ${ }^{158}$

Several misconceptions seem prevalent among determination officials. It is assumed, for instance, that "only political persecution counts as persecution $^{\text {159 }}$ although four other grounds are recognised in the Refugee Convention. "Political opinion" in turn is most narrowly construed. In a case cited by Amnesty International ${ }^{160}$, the immigration officer, having established that the asylum-seeker criticised the Vietnamese Government, was not allowed to study and had to return to his home village for re-education, proceeded to observe that "this was in conformity with the Government policy which forbade independent criticism of the party of Government." The officer concluded that such criticism did not amount to holding political opinion and that there was no indication that the asylumseeker had fear of persecution for holding such opinion.

Even more striking is the case of an asylum-seeker who evidently failed to convince the immigration officers that he suffered "political persecution" despite the fact that he had been tried and convicted by the Vietnamese authorities for "crimes against the state" for his political activities during a stay in Czechoslovakia for a few years earlier. ${ }^{161}$

Indeed, the notion of "persecution" itself seems to be associated by screening officials with the "most grotesque forms of persecution ${ }^{162}$ while

155. Such as showing sympathy and compassion only to members of family - see in this connection S.K. LAU \& H.C.KUAN, The Ethos of the Hong Kong Chinese (The Chinese University Press, 1988) pp.59-62; xenophobic prejudices against non-local Chinese - see in this connection A.H.YEE, A People Misruled, Hong Kong and the Chinese Stepping Stone Syndrome (API Press, 1989) p.156 et seq.

156. Such as responsiveness to domestic pressures; or latent fears that refugees may secure places in the West at the expense of would-be Hong Kong emigrants.

157. See Amnesty Memorandum, supra n.98 at pp.20, 27.

158. See Lawyers' Report, supra n.103 at 22.

159. Lawyers Report, supra n.103 at p.23.

160. Amnesty Memorandum, supra n.98 atp.20.

161. Amnesty Memorandum, supra n.98 at p.27.

162. Lawyers' Report, supra n.103 at p.23. 
rejecting harassment and discrimination as persecution" ${ }^{163}$ Such a perception apparently led to the refusal of refugee status to a Catholic couple who were subjected to mandatory "re-education" sessions following attendance at Mass on Catholic Holy Days ${ }^{164}$ or to a Catholic choir girl, repeatedly discriminated against at school and denied employment in government establishments, whose brother was shot by the police (as part of their efforts to intimidate Catholics into giving up their faith) and whose own arrest had been authorised following a discovery in her house of Catholic song books. ${ }^{165}$

Nor are officials open to the idea that severe economic deprivation may constitute persecution. Claims of confiscation by the Vietnamese Government of Registration Certificates or Ration Cards - and the serious economic implication which it entails (inability to support one's self or family) have been assessed as a mere "economic grievance." $)^{166}$ Of similar insignificance are considered forced relocations to New Economic Zones (NEZ) ${ }^{167}$ although in effect such moves mean deprivation of one's right to earn a livelihood and hence "persecution".

Equally false is the view reflected in officers' comments ${ }^{168}$ that a general policy, such as re-education, directed against "the enemies of the Communist regime" cannot be "persecution" and that in the absence of "singling out for special treatment" no fear of persecution can be established. Unappreciated, at the same time, is the fact that persecution or deprivation of economic or social rights by family members give rise to fear of persecution even before actual suffering is inflicted.

Misconceptions and wrong interpretations aside, determination of refugee claims in Hong Kong is further distorted by serious administrative flaws. Perhaps the most glaring administrative defect which has a potentially restrictive effect on refugee criteria application is the failure of the Review Board to hear claimants personally and the Board's exclusive reliance on interview transcripts (which asylum-seekers are not afforded opportunity to read or correct) compiled by examining officers lacking

163. Note that those who experience serious discrimination resulting in substantially prejudicial consequences, such as restrictions on the right to earn a livelihood or to have access to normally available schooling, suffer persecution and are Convention refugees - UNCR Handbook, para. 54. In fact, even lesser measures of discrimination may amount to the persecution necessary for Convention refugee status if they reasonably produce an apprehension and insecurity regarding a person's future existence - UNHCR Handbook, para. 55.

164. Amnesty Memorandum, supra n.98 at p.20.

165. See CoHEN, “A Case against Screening”. SCMP 11 June 1990.

166. Lawyers Report, supra n.103 at p.24.

167. See Amnesty Memorandum, supra n.98 at p.20.

168. As per Lawyers' Report, supra n.103 at p.23. 
sufficient knowledge of human rights and relevant international refugee law.

Unlike their British counterparts, however, Hong Kong decision-makers are unlikely to be provided with local authoritative jurisprudence concerning refugee criteria. As demonstrated recently in the appeal case of Madam Lee Bun and Lee Ching Ming v. The Director of Immigration ${ }^{169}$, the Hong Kong courts would not consider arguments based on the Refugee Convention since "[i]t is common ground that although the United Kingdom has ratified the Convention and that it has been extended to many, if not most, of Her Majesty's other dominions, it has not been extended to Hong Kong." Furthermore, "the Secretary of State, when exercising statutory powers is not obliged to have regard to a Convention which has not become part of domestic law; a fortiori then, with respect to Hong Kong, when the Crown is not even party to the Convention. ${ }^{170}$

Nor are local judges amenable to arguments from customary international law ${ }^{171}$ and, as they cautiously observed in the Lee Bun decision, "in some countries, including the United Kingdom, it is not open to a litigant in domestic courts to rely upon [a principle of customary international law] in the face of inconsistent legislation." 172

In fact, the opportunity for the Hong Kong courts to pronounce on principles of refugee determination status is particularly limited in the light of Section $13 \mathrm{~F}(8)$ of the Immigration (Amendment) (No.2) Ordinance 1989 which stipulates that "a decision of the [Refugee Status Review Board] shall not be subject to review or appeal in any court." An application for judicial review to challenge administrative irregularities, if successful, is likely to generate at best judicial statements concerning procedural proprieties as distinct from substantive refugee determination standards.

\section{STANDARDS OF TREATMENT - DETENTION}

\subsection{International Rules}

\subsubsection{Legality of Detention}

The right to liberty and security of the person is one of the most funda-

169. Civil Appeal No. 54 \& 55, judgment of 29 June 1990.

170. Per Sir Derek Cons, V.P., ibid. at p.6.

171. See R.MUSHKAT, "International Human Rights Law and Domestic Hong Kong Law" in WACKS (ed.), A Bill of Rights (1990) at pp.25-28.

172. Supra n.169 at p.7. 
mental of all human rights and is proclaimed in all major international human rights instruments. ${ }^{173}$ Specifically, all persons are guaranteed a right not to be subjected to arbitrary arrest or detention ${ }^{174}$ except on grounds, and by procedures, "established by law."

The freedom from arbitrary arrest and detention has been further reaffirmed by international and domestic tribunals. Most notably, the International Court of Justice in the Hostages Case stated unequivocally that "[w]rongfully to deprive human beings of their freedom and to subject them to physical constraint in conditions of hardship is in itself manifestly incompatible with the principles of the Charter of the UN, as well as the fundamental principles enunciated in the Universal Declaration of Human Rights. $^{\text {175 }}$ The European Court of Human Rights was even more specific when pronouncing that the "purpose of the [EHR]... is to protect the freedom and security of the individual against arbitrary detention or arrest ${ }^{\text {1176 }}$ and that in a democratic society subscribing to the rule of law... no detention that is arbitrary can even be regarded as 'lawful'. ${ }^{n 177}$ At the national level, particularly significant are decisions of the US court regarding aliens which recognised that arbitrary detention was a principle of customary international law. ${ }^{178}$

In fact, special international rules have developed with respect to detention of non-nationals, asylum-seekers and refugees. Thus, Article 5 of the 1985 UN Declaration on the Human Rights of Individuals Who Are Not Nationals of the Country in Which They Live ${ }^{179}$ reaffirms the prohibition on the arbitrary arrest and detention of non-nationals. Similarly, the 1951 Refugee Convention has recognised that the distinctive position of asylum-seekers and refugees (in flight from persecution and in search of protection) needs to be taken into account as far as penalties for illegal entry and measures of detention are concerned. ${ }^{180}$ The Executive Committee of the UNHCR has also laid down as one of the "minimum basic human standards of treatment of refugees and asylum-seekers" the requirement that they "should not be penalised or exposed to any unfavourable treatment

173. Universal Declaration of Human Rights [UDHR] (Art. 3); International Covenant on Civil and Political Rights [ICCPR] (Art. 9(1)); the European Convention on Human Rights [EConHR] (Art.5(1)); American Convention on Human Rights [ACHR] (Art. 7(1)); African Charter on Human and Peoples' Rights [ACHPR] (Art. 6).

174. UDHR Art. 9; ICCPR Art. 9(1); EConHR Art. 5(1); ACHR Art. 7(3); ACHPR Art. 6.

175. US Diplomatic and Consular Staff in Tehran, (US $v$. Iran), [1980] ICJ Rep. 3, 42.

176. Lawless Case, ECHR, Ser.A, Vol.3 at 52 (Judgment of 1 July 1961).

177. Winterwerp Case, ECHR, Ser.A, Vol.33 at 18 (Judgment of 24 October 1979).

178. See cases cited in: Inhuman Deterrence. The Treatment of Vietnamese Boat People in Hong Kong, Lawyers Committee for Human Rights (mimeographed, 1989) [hereafter: Inhuman Deterrence] at 62 and $63 \mathrm{n}$.

179. G.A.Res.A/40/44 (13 Dec. 1985). 
solely on the ground that their presence in the country is considered unlawful; and that they should not be subjected to restrictions on their movements other than those which are necessary in the interest of public health and public order." ${ }^{181}$

While exceptions to the prescribed rules are recognised and derogation from standards permitted under certain circumstances, the basic principle is that detention of refugees and asylum-seekers "should only be resorted to when a genuine necessity exists" 182 and, if applied, "should not be unduly prolonged" (it may last only as long as the exigencies of the situation demand). ${ }^{183}$

It is acknowledged, for example, that in individual cases some initial period of deprivation or limitation of freedom of movement may be necessary for administrative reasons or "solely with a view to determining the identity of the applicant, his or her background, and the basis of the claim to refugee status or asylum. Detention beyond the initial period ought to be based only on the most serious reasons, such as criminal associations or intent, or the fact that the person is likely to abscond. ${ }^{\text {n184 }}$

In situations of mass influx, which inevitably bring into play a more complex set of factors, the grounds for detention are more wide-ranging, including in addition to identity verification and eligibility determination also the protection of national security or public order. ${ }^{185}$ However, such considerations in themselves are insufficient and must satisfy the test of "necessity" which, in turn, incorporates the principle of proportionality. ${ }^{186}$

Apart from the substantive restrictions imposed on resort to the exceptional measure of detention, authorities in the receiving states are also constrained by requirements of procedural justice, including the availabil-

180. Art. 31 provides: "1. The Contracting States shall not impose penalties, on account of their illegal entry or presence, on refugees who, coming directly from a territory where their life or freedom was threatened... enter or are present in their territory without authorisation... 2.The Contracting States shall not apply to the movements of such refugees restrictions other than those which are necessary..." Note also Art. 26 which prescribes such freedom of movement for refugees as is accorded to aliens generally in the same circumstances.

181. EXCOM Conclusion No. 22 (XXXID) on Protection of Asylum-Seekers in Situations of Large-Scale Influx (1981); text incorporated in the Annex, Background Documentation, Study on Detention of Refugees and Asylum 3 Seekers (Florence: International Institute of Humanitarian Law, Une 1984) at p.39.

182. See EXCOM 37th Session, Note on Accession to International Instruments and the Detention of Rerugees and Asylum Seekers, EC/SCP/44, 19 Aug. 1986, para. 51(b).

183. See Working Group on the Treatment of Refugees with Particular Reference to the Problem of Detention (Florence: 3-5 June 1984), "Conclusions on the Detention of Refugees and Asylum-Seekers" [hereafter: Working Group on Detention-Conclusions] para.II.

184. Working Group on Detention-Conclusions, ibid. para. III.

185. EXCOM Conclusion No. 44, para. (b).

186. See P.SIEGHART, The Lawful Rights of Mankind (Oxford University Press, 1985) at p.94. 
ity of review and appeal provisions, access to legal counsel as well as opportunity for the grant of provisional liberty on suitable conditions. ${ }^{187}$

Common to both the substantive and procedural strictures is the norm underlying human rights law in general, namely that the rights protected be exercised "without discrimination of any kind as to race, colour, sex, language, religion, political or other opinion, national or social origin property, birth or other status. ${ }^{\text {188 }}$

\subsubsection{Conditions of Detention}

International rules governing conditions of detention stem from several sources relating to both detainees in general and the particular predicament of asylum-seekers and refugees. Regardless of their source, however, the rules are underpinned by the common general norms that "no one shall be subjected to torture or to cruel, inhuman or degrading treatment and punishment" ${ }^{189}$ and that "all persons deprived of their liberty shall be treated with humanity and with respect for the inherent dignity of the human person. ${ }^{190}$

Such norms are reflected in what are considered the basic international prison regulations, the UN Standard Minimum Rules for the Treatment of Prisoners ${ }^{191}$ (as extended to persons arrested or imprisoned without charge) ${ }^{192}$ as well as in their regional counterpart, the Standard Minimum Rules for the Treatment of Prisoners promulgated by the European Committee on Crime Problems of the Council of Europe. ${ }^{193}$

Similarly oriented is the Code of Conduct for Law Enforcement Officials ${ }^{194}$ which provides that "[i]n the performance of their duty, law enforcement officials shall respect and protect human dignity and maintain

187. EXCOM Conclusion No. 44, para. (e); Working Group on Detentio - Conclusions, para. III; 1988 UN Body of Principles for the Protection of all Persons under any Form of Detention or Imprisonment, G.A.Res.A/43/173 (Dec. 1988) [hereafter: Body of Principles].

188. See Art. 2(1) ICCPR; Arts 5, 6 International Convention on the Elimination of All Forms of Racial Discrimination; Principle 4, Body of Principles. Note also the statement by the European Commission of Human Rights in the East African Asians Cases (Admissibility), 13 YBECHR 928, 994 (1970) that "discrimination based on race could, in certain circumstances, of itself amount to degrading treatment within the meaning of Article $3 .^{n}$

189. Art. 5 UDHR; Art. 7 ICCPR; Art. 3 EConHR; Art. 5(2) ACHR.

190. Art. 10(1) ICCPR; Art. 7(2) ACHR.

191. Adopted 30 Aug. 1955 by the First UN Congress on the Prevention of Crime and the Treatment of Offenders, UN Doc.A/CONF 6/1 Annex I, paras 31,54; Adopted 31 July 1957 by the Economic and Social Council, ECOSOC Res. 663 (XXIV) C, 24 UN ECOSOC Off. Rec. Supp. (No. 1) 11 (UN Doc. E/3048) (1957).

192. ECOSOC Res. 2076, 62 UN ECOSOC Off. Rec. Supp.(No.1) 35, (UN Doc. E/5988) (1977).

193. Council of Europe, Res.73(5) (1973) adopted by the Council of Ministers on 19 Jan. 1973 at the 217th Meeting of the Ministers' Deputies.

194. Adopted by UN G.A.Res. 34/169 (17 Dec. 1979). 
and uphold the human rights of all persons." A more recent reaffirmation of the right of "all persons under any form of detention or imprisonment" to "be treated with humanity and with respect for the inherent dignity of the human person" and not to "be subjected to torture or to cruel, inhuman or degrading treatment or punishment" (to be "interpreted so as to extend the widest possible protection against abuses, whether physical or mental") is contained in the comprehensive Body of Principles for the Protection of All Persons under Any Form of Detention or Imprisonment. ${ }^{195}$

Needless to say, humane treatment is mandated under international rules pertaining to asylum-seekers and refugees "whose tragic plight requires special understanding and sympathy. ${ }^{n 196}$ Conditions of detention should in no case fall below the "basic human standards" embodies in EXCOM Conclusion No. 22 of $1981 .{ }^{197}$ In particular, asylum-seekers should be located by reference to their safety and well being as well as the security of the state of refuge; be provided with the basic necessities of life; their family unity be respected and assistance in tracing relatives be given; minors and unaccompanied children be adequately protected; sending and receiving mail and receipt of material assistance from friends be allowed and where possible appropriate arrangements be made for the registration of births, deaths and marriages.

\subsection{The British Position}

\subsubsection{Legality of Detention}

Under UK immigration law, "administrative detention" (as distinct from custody following an arrest for an immigration or related offence) is only authorised pending the removal of the person from the UK. ${ }^{198}$ As held in Re Hardial Sing $h^{199}$, the power given to the Home Secretary (as well as to immigration officers with respect to certain categories of persons) to detain should not be used for any purpose other than pending removal. Such power was further restricted to the period reasonably required for this purpose. It was also implicit that the Home Secretary should act expedi-

195. Supra n.187, Principles 1 and 4.

196. See Conclusion (m) in EXCOM: Note on Detention 1986, supra n. 182 at p.14.

197. Supra n. 181.

198. Two exceptions are recognised - under Immigration Act 1971, Schedule 2, paras $2 \& 16$ and Schedule 3, para. 2(2) - but for specific and obvious reasons. Thus a newly arrived passenger may be detained pending further examination and detention may be imposed following a decision or recommendation to deport where no deportation order has yet been made. 199. [1983] Imm.AR $198 \mathrm{sb}$ nom R $v$. Governor of Durham Prison, ex parte Singh, [1984]. 1 All ER 983, [1984] 1 WLR 704, QBD. 
tiously to ensure that all necessary steps were taken for removal within a reasonable time. A failure to take the action required or to take it sufficiently promptly will render the detention unlawful.

In fact, the power to detain granted to the immigration authorities is discretionary and may be disposed with. Detention may be substituted with a temporary release or admission subject to restrictions as to residence and reporting to the police. ${ }^{200}$

Some provisions are also made under the Immigration Act for application for bail by new arrivals who have been detained for more than seven days pending their examination ${ }^{201}$ and for those who have an appeal pending before an adjudicator (e.g. a "destination appeal" objecting to the country or territory to which the appellant is to be removed) or the Appeal Tribunal. ${ }^{202}$

In addition, as reaffirmed in $R v$. Secretary for State for the Home Department ex parte $S w a t i^{203}$, where an applicant is in legal custody pending examination or removal, the courts have an inherent jurisdiction to grant bail, although "in the light of the statutory powers available to the Secretary of State and to adjudicators it would be exercised only in exceptional circumstances, and only if leave to apply for judicial review had been granted."

It is clear in any event that the legality of detention can be challenged by way of habeas corpus or judicial review. Indeed, in cases concerning removal of "illegal entrants" (persons who obtained leave to enter the UK by practicing fraud or deception in contravention of the Immigration Act) British courts have assumed a wide power to inquire into the truth of the jurisdictional basis upon which the illegal entry decision rested. ${ }^{204}$

Failing to obtain redress from the UK immigration authorities or courts, aggrieved detainees alleging violations of their right to liberty and security (under Article 5(1) of the European convention on Human Rights) may also petition the European Commission of Human Rights. ${ }^{205}$

200. Immigration Act 1971, Schedule 2, para. 2(1) \& (2). Note the recommendation by the Home Affairs Sub-Committee on Race Relations and Immigration in its Report on Refugees and Asylum with Special Reference to the Vietnamese, 1984-5 [hereafter:SCORRI Report] para. 109 - that "in normal circumstances asylum-seekers at ports of entry who would otherwise be detained be granted temporary admission to a refugee hostel or other suitable or accepted accomodation."

201. Immigration Act 1971, Schedule 2, para. 22(1).

202. Ibid. para. 29.

203. [1986] 1 WLR 477, 485-6 (per DonALDSON M.R.).

204. See Kharwaja $v$. Secretary of State for the Home Department, [1983] 1 All ER 765 (HR); different considerations apply in cases concerning refusal of leve to enter where all relevant decisions of fact as well as the application and any necessary exercise of discretion are entrusted to immigration officers - ibid. at 790 (per Lord BRIDGE). 


\subsubsection{Conditions of Detention}

Persons detained pending removal or deportation are deemed to be in "legal custody"206 and hence subject to the law governing the prison system in the United Kingdom, namely the Prison Act 1952 and the Prison rules 1964 (as amended).

Like other prisoners they are guaranteed certain rights and recourse to institutional enforcement, including to the Parliamentary Commission for Administration through a Member of Parliament and to the European Commission of Human Rights (before which they may challenge the Prison Rules themselves as well as violations of the Rules). They could also rely on general civil and criminal law for protection by the courts. ${ }^{207}$

\subsection{Regional Attitudes}

\subsubsection{Legality of Detention}

No Asian country has incorporated a specific exemption from penalties for illegal entry or presence of asylum-seekers. Rather, in line with prevailing policies of "humane deterrence" Indo-Chinese arrivals have invariably been designated "illegal immigrants" and consequently exposed to the risk of prosecution, punishment, detention or deportation.

In practice, the enforcement of immigration rules in the region is to a large extent a function of the policies of the governments in power which in turn are influenced by ad hoc factors such as size of the influx, repatriation prospects, resettlement opportunities, availability of foreign aid and attitudes towards the country of origin. ${ }^{208}$

205. See cases cited in I.A.MACDONALD, Immigration Law and Practice in the United Kingdom, 2nd edn. (Butterworths, 1987) at p.295-7.

206. Immigration Act 1971, Schedule 2, para. 18(4).

207. In the case of some breaches of the Prison Rules - e.g., the use of unnecessary force by a prison officer against a prisoner - there will be a remedy in tort or in criminal law.

208. Note, for example, the different treatment accorded by the Thai Government to Vietnamese, Kampucheans, Laotians and Burmese - see V.MuNTARBHORN, "Asylum in Thailand" (forthcoming). MUNTARBHORN recounts the various changes in policies by the Royal Thai Government, including the introduction in 1980 of the "humane deterrence" policy covering four basic tenets: (1) the closing of the Thai border to new arrivals; (2) detention of illegal entrants in camps characterised by harsh conditions; (3) no resettlement for new arrivals; and (4) "minimum standard of treatment" - not higher than strictly necessary for subsistence. The author also observes that the presence of international humanitarian organisations, such as the UNHCR and the ICRC, "acts as a disincentive against too strict enforcement of immigration law against asylum-seekers" 
Whether founded upon the illegal entrance of the asylum-seekers or not, it is evident that detention measures implemented in the region are not predicated on legitimate reasons (such as serious threat to the community or to national security or the likelihood of abscondment). Nor are they contingent upon determination of refugee status or other specific objectives but are maintained pending a "resolution of the situation." By the same token, political realities militate against utilisation of the judicial or administrative review even if such provisions might theoretically be available under the regional constitutions or laws.

\subsubsection{Conditions of Detention}

Although, with the exception of the Philippines, none of the first asylum countries in the region are parties to the Refugee Convention or its Protocol, they have accepted UNHCR protective role and at least one country (Thailand) is a member of its Executive Committee. As such they may be assumed to be guided by the UNHCR conclusions concerning protection of asylum-seekers. Minimum standards of treatment are also contained in the regionally important instrument of Principles concerning the Treatment of Refugees, adopted by the Asian African Legal Consultative Committee in 1966 (as supplemented in 1970 and 1987).

Indeed, to varying degrees conditions in the region's camps adhere to the prescribed standards. It may also be noted that while some form of detention of asylum-seekers is practiced by all first asylum countries in the region, the extent of physical and psychological confinement differs according to circumstances. Thus, for example, in camps located away from major population centres and managed by voluntary relief agencies, detainees enjoy greater autonomy. ${ }^{209}$

\subsection{The Hong Kong Approach}

\subsubsection{Legality of Detention}

Not unlike other countries of first asylum, Hong Kong has responded to the continuing influx of Indo-Chinese boat people in a period of "compas-

209. In Malaysia's main camp, which is located on an island and administered by the Malaysian Red Crescent Society, "the Vietnamese run their own show, they have their own government and camp committee", as reported in K.GRIFFIN \& J.NIP, "HK Camps Worst in Region", SCMP 29 Oct. 1989. Freedom of movement is also enjoyed by the population of the Philippines's First Asylum Camp in the Island of Palawan (ibid.). More restrictive are Thailand's camps (not the border camps) which are managed by the Thai Ministry of the Interior (and located amongst the poorest villages in Thailand) although "much of the work in the camps was farmed out to the Vietnamese" (ibid.). 
sion fatigue" with its own version of "humane deterrence." Thus, 1982 saw the introduction of detention of arrivals in closed camps to be followed by strict deterrent measures in June 1988 with the establishment of detention centres for the incarceration of asylum-seekers awaiting determination of refugee status and for those "screened out."

Yet, notwithstanding its regional "compatibility" and pragmatic inevitability, Hong Kong's policy of confining Vietnamese refugees in closed camps and asylum-seekers in detention centres deviates from the international standards outlined above. ${ }^{210}$ To begin with, it lacks a legitimate aim; it is not predicated upon a particular conduct or omission and does not depend on the establishment of justificatory facts (such as suspected criminal intent, activity or association and the likelihood of absconding). Nor is it related to the prospect of removal to the country of origin or based on considerations of national security or public safety.

The Government's declared aim of discouraging further arrivals as part of a programme of "humane deterrence ${ }^{n 211}$ cannot be regarded as legitimate (or, for that matter, humane) and is "never justifiable under international law." 212 Indeed, it has been argued that such a policy is "wholly inconsistent with the ...international system for the protection of refugees" as it is "likely to increase the risk to individuals still in a country where they risk human rights violations by discouraging them from leaving to seek asylum in a country where they believe they will be detained indefinitely on arrival. ${ }^{n 213}$ Some critics have gone even further to suggest that the detention measures employed by the Hong Kong Government breach the fundamental norm of non-refoulement since they constitute "constructive refoulement by deterring people whose life or freedom is threatened from exercising their right to seek asylum or - once arrived effectively forcing them to abandon their claim for asylum and volunteer to return to a country where their life or freedom is in danger. ${ }^{n 214}$

In addition to the apparent illegitimacy of their aim, the Hong Kong authorities seeking to justify the detention policy would be unable to satisfy international requirements of "necessity." Thus, they would have considerable difficulty in showing a reasonable relationship between detention and the objective which it claims to underpin. The putative causal rela-

210. The following analysis is largely a reproduction of arguments advanced by the author in her article on "Refuge in Hong Kong”, 1 IJRL (1989), at pp.449, 457-466.

211. See statement by R.LucE, (ex) Minister of State, Foreign and Commonwealth Office: "We had to have closed camps introduced as from summer 1982 as a policy of humane deterrence." SCORRI Report, supra n.100, Vol. II, at p.145 (Q 217).

212. Working Group on Detention - Conclusions, supra n.183, Sec.III at p.6.

213. Amnesty Memorandum, supra n.98 at p.48.

214. See IRAC Report, supra n.23 at pp.77n, 90, 91. 
tionship might be said to exist, were there some tangible evidence that detention constituted an effective deterrence. Such evidence, however, is lacking. While the relevant figures show a marked decline in the number of arrivals - and at a faster rate than elsewhere in the region - subsequent to the introduction of closed centres ${ }^{215}$ it is by no means clear that this reversal of trend can be attributed solely to the policy of closed centres rather than to the territory's slow rate of resettlement or other factors, particularly since other States in the region implemented detention measures as well. Indeed, an upsurge in arrivals occurred in 1988 and 1989 while the detention and deterrence policies remained in force ${ }^{216}$ and more than 48,473 arrived since screening was introduced. ${ }^{217}$

In spite of the Government's extensive publicity effort which utilizes multiple channels to convey the message of detention and the remote prospect of resettlement and the fact that Vietnamese boat people arriving in Hong Kong are provided with the option of "continuing their journey" with local assistance, ${ }^{218}$ asylum-seekers from Vietnam still find the territory attractive.

Nor can proportionality between means and ends be established by resorting to a cost-benefit calculus. The adverse psychological consequences of prolonged detention and the "danger of creating a 'hard core' who

215. In 1983 arrivals were $53 \%$ less than those in 1982 compared with a regional decline of $36 \%$; in 1984 and 1985 the Hong Kong decrease was $39 \%$ and $44 \%$ respectively, and that of the region $11 \%$ and $14 \%$ respectively, per information supplied by the Chief Executive Officer (Refugees), Refugee Division, Security Branch.

216. The number of arrivals in 1989 was almost twice the 1988 figure and ten times that of 1987: 34,116 Vietnamese reached the territory in 1989 compared with 18,328 for the whole of 1988 and 3395 in 1987. See V. LEE, "Influx of Vietnamese Double Previous Year", SCMP 30 Dec. 1989.

217. Per information received on 15 Aug. 1990 from Refugee Division Security Branch.

218. The following notice was despatched to the boat people in the period from July 1982 June 1988: "All former residents of Vietnam seeking to enter Hong Kong since July 1982 are detained in special centres. If you do not leave Hong Kong now, you will be taken to a closed centre and detained there indefinitely. You will not be permitted to leave the detention during the time you remain in Hong Kong. It is extremely unlikely that any opportunity for resettlement will be forthcoming. You are free to leave Hong Kong now, and if you choose to continue your journey will be given assistance to do so." In June 1988, the "Warning Notice" given to Vietnamese entering Hong Kong waters read:"There is a new policy in force in Hong Kong. Former residents of Vietnam seeking to enter Hong Kong as economic migrants are now treated as illegal immigrants. You are free to leave Hong Kng. If you choose to continue your journey you will be given food and water and, if necessary, your boat will be repaired. If you do not leave Hong Kong and are found to be an economic migrant you will be detained as an illegal immigrant pending repatriation to Vietnam." A similar communication is contained in a revised "Notice on Arrival", introduced in September 1988 (to reflect more accurately the initial status of arrivals as "asylum-seeker" as distinct from "illegal immigrants"), as follows: "Former residents of Vietnam seeking to enter Hong Kong are now subject to a process to decide whether or not they are refugees as defined in the 1951 UN Convention Relating to the Status of Refugees. Those found not to be refugees will be treated as illegal immigrants. As an illegal immigrant you will be detained pending repatriation to Vietnam. However, you are free to leave Hong Kong if you choose to continue your journey, you will be given food, water, and if necessary, your boat will be repaired." 
would be almost impossible to resettle anywhere" constitute social costs that outweigh any possible benefits. Unfortunately, the negative effects are of a long-term nature and do not lend themselves easily to quantification. Hence utilitarian policy-makers see no compelling reasons to reassess their strategy.

Finally, the Hong Kong Government would not be able to claim "necessity $^{n}$ by reference to internationally recognised grounds for departure from basic freedoms such as "national security", "public order" or "public safety." The large inflow of asylum-seekers

doubtless imposes some burden on the territory, but their is no solid evidence that it constitutes a serious threat to public order or to the general welfare - physical, economic or moral - of the community. The argument that in the absence of detention the number of Vietnamese arrivals would escalate and render the administration of the refugee problem unmanageable, endangering in the process the well-being of the population at large, is difficult to substantiate in view of Hong Kong's impressive record of crisis management. ${ }^{219}$

Legality and necessity aside, the local practice of detention of asylumseekers and refugees fails to meet the procedural safeguards laid down by the international community seeking to protect those prone to abuse. In particular, no right to challenge the lawfulness of detention is afforded the detainees under Hong Kong's immigration law. Indeed, it is doubtful whether an application for review of a detention order is likely to succeed given that such an order is authorised under the Immigration Ordinance (Section 13A) and that the legality of duly passed legislation is not subject to review by the courts under the territory's present legal system.

Nor can a case founded on the ground of discrimination be brought before the local courts in the absence of the relevant constitutional guarantees, notwithstanding the international legal validity of the claim by Vietnamese detainees that they are victims of discrimination as other aliens under the Immigration Ordinance may not be detained unless there is a risk that they might abscond or that they constitute a threat to national security. 220

An aggrieved asylum seeker or refugee seeking to vindicate his or her rights under the relevant conventions would likewise be unable to secure redress at the international level. This ultimate option cannot be exercised

219. Note that Hong Kong coped reasonably well with large influxes - exceeding in one year (1980) 84,000 - notwithstanding their unrestricted movement and access to employment in Hong Kong.

220. One observer has speculated, however, that a request may be made that Vietnamese detainees be allowed the same opportunity as other aliens for release upon recognizance. See IRAC Report, supra n.23 at p. 100 . 
since the United Kingdom has not signed the Optional Protocol to the International Covenant on Civil and Political Rights, has not extended the European Convention on Human Rights to Hong Kong and has not accepted the competence of the European Commission of Human Rights to receive petitions in respect of matters occurring within the territory. ${ }^{221}$

\subsubsection{Conditions of Detention}

Conditions in closed and detention centres in Hong Kong have been the subject to much criticism by international human rights and relief organisations. The territory's camps have even been said to be "the most repressive in the region" because of the "stronger security presence, the fact that "boat people have little to say over their lives, and even the children [are] treated like prisoners. ${ }^{n 222}$ Critics have stopped short however of concluding that such conditions constituted cruel, inhuman or degrading treatment of the detained asylum-seekers. ${ }^{23}$ They have nonetheless proceeded to decry the absence in general of humanity and regard to the inherent dignity of the human person as prescribed under the relevant international norms and have condemned the various departures from generally recognised international standards as well as the infringements of Hong Kong's own law.

Of particular concern have been incidents of reported abuses and mistreatment by government officers ${ }^{224}$ which, as one observer has concluded, "violated all applicable rules" including Hong Kong's Closed Centre Rules ${ }^{225}$ and Prison Rules ${ }^{226}$ and were hardly in keeping with the Government's commitment ${ }^{227}$ to treat asylum-seekers in a "humane and dignified manner."

Claims of violations of detainees' physical integrity have also been made in relation to the punitive detention measures employed against sodesignated "trouble-makers" in the absence of sufficient legal safeguards. Questions have been raised as to the legality of the transfer from a deten-

221. See decision of 12 Mar. 1990 by the European Commission of Human Rights as to admissibility of Application $16137 / 90$ by Bui Van Than \& Others against the United Kingdom. The application was dismissed as inadmissible on jurisdictional grounds.

222. See K.GRIFFin \& J.NiP, “HK Camps Worst in Region - Amnesty” (SCMP 29 Oct. 1989), quoting refugee relief workers with experience across Asia. Note, however, recent endorsement by the Government of a report which detailed measures aimed at vastly increasing the involvement of Vietnamese internees in the day-to-day operation of the largest detention centre in Hong Kong. See F.MACMAHON, "UNHCR Endorsement for Report on Whitehead", SCMP 16 June 1990. A seminar was also organised by the Government with a view to finding "ways to make life more tolerable for the Vietnamese boat people". See F.MACMAHON, "Seminar Called to Improve Centres", SCMP 18 June 1990.

223. One exception was identified regarding a temporary centre which has since closed. Amnesty Memorandum, supra n. 98 at pp.45-6. 
tion centre to a maximum security camp of persons not charged with any offence against the laws of Hong Kong. ${ }^{228}$ Critics draw a special attention to the potential ${ }^{229}$ for abuse given that there is "no formal process whereby a determination of 'trouble-maker' status is made, nor any procedure involving a hearing for the individual concerned before such a determination is made. ${ }^{230}$

It appears, however, that the authorities are given wide disciplinary power under the Closed Centres Rules which also include a provision that a detainee is deemed to have committed an offence if he or she "in any way offends good order and discipline" [Rule 34(k)]. While an aggrieved asylum-seeker may be able to apply for a writ of habeas corpus ${ }^{231}$, the chances of success seem remote, particularly in the light of a recent decision by a Hong Kong High Court judge to reject such an application brought by two

\begin{abstract}
224. An inquiry into an incident at Hei Ling Chau Detention Centre by two Justices of the Peace has confirmed the unnecessary use of force by Correctional Services Department Officers on many asylum-seekers who had not resisted any order and the attempts by the officers to suppress allegation of assault on the asylum-seekers. See CHANG \& PETERSON, "Report of Justices of Peace on Complaints Concerning the Treatment of Vietnamese Boat People at Hei Ling Chau on 18 and 19 July 1988" (29 Sept. 1988) at pp.35-38. Amnesty Memorandum contains a detailed account pertaining to assaults by officers of the HK Royal Police Force at the Shek Kong Detention Centre on the night of 23-24 July 1989 resulting in the death of one asylum-seeker and injuries of more than one-hundred detainees: supra n. 98 at pp.31-39. Undue force was also alleged to have been used by members of the Tactical Response Squad of the CSD during the forcible removal of 48 "screened out" asylum-seekers from Chi Ma Wan Detention Centre to the Phoenix House Detention Centre in the early morning hours of 31 Oct. 1989: Amnesty Memorandum, supra n. 98 at pp.39-44. On 4 May 1990 a weapon search operation conducted by the police ( 1200 officers) in the territory's largest detention centre (Whitehead) has triggered fierce allegations by the Centre's inmates concerning the "inhumane acts by the Royal HK Police Force" during the operation, the "acts of oppression, barbarous beating and corporal punishment" - "in the face of no resistance" - "somewhat like the acts of the Nazis to the Jews in 1936" (a letter sent to the Governor, as cited in F. MACMAHON, "Detainees Demand Inquiry on Raid", SCMP 12 May 1990). See also protest by the UNHCR regarding the "use of tear gas (106 rounds were fired) directed in enclosed spaces at a camp population comprising large number of women and children (8,532 out of 22,294 are children under the age of 17 and 6,187 are women) and other vulnerable persons during a massive weapons search." The UNHCR further contended that " $[t]$ he reported abuses of asylum seekers during the operation, and the wide scale destruction of personal property as well as extreme damage to education facilities can... have no result but further radicalise the centre population and increase the risk of even more tension and violence". Cited in F.MACMAHON, "UNHCR in Protest over Camp Search", SCMP 12 May 1990.
\end{abstract}

225. Immigration (Vietnamese Refugee Centre) (Closed Centre) Rules, Immigration Ordinance, Cap.115, Laws of Hong Kong (1982 edn.) Rule 36.

226. Prison Rules, Prison Ordinance, Cap.234, Laws of Hong Kong, Rule 237.

227. Statement of Understanding, supra, para. 1.

228. See letter sent to the Chairman of the Bar Association Human Rights Sub-Committee, cited in S. GREen, "A Camp Heading for Trouble", SCMP 19 July 1990.

229. Some allegations have been made that those removed were in fact community leaders expressing dissent in connection with forced repatriation. See Report of the Delegatin of the Women's Commission for Refugee Women and Children to Hong Kong (Jan. 5-12, 1990) at p.10.

230. Supra, n.228.

231. By virtue of Sec. 13BA of the Immigration Ordinance. 
asylum-seekers who had been moved to a prison after disturbance at a detention centre. The judge, accepting as valid authorisation produced by the Director of Immigration, held that the latter had properly exercised his discretion. ${ }^{232}$

\section{SOLUTIONS}

\subsection{Voluntary Repatriation}

\subsubsection{International Rules}

Ranked as a "basic or primordial solution" 233 , voluntary repatriation is firmly grounded in human rights law and has as its main concern the safety and well-being of the refugees. Fundamental to this solution is the right of persons to return voluntarily to their country of origin ${ }^{234}$ under conditions of safety and dignity. ${ }^{235}$

"Voluntariness" in turn has been interpreted and elaborated in numerous international forums as presupposing "freely expressed wish of the refugees themselves ${ }^{\text {236 }}$ "based on full information [of the situation in the country of origin, including information regarding the extent to which repatriates will be assisted and protected upon return] and freedom from constrain [levels of assistance in the country of refuge must not have decreased so as to induce refugees to return to their country of origin]. ${ }^{\text {237 }}$

It also presupposes the "elimination or at least the substantial removal of the cause of fear or danger which had led to the departure of refugees from their home country ${ }^{n 38}$ as well as the "willingness of the country of

232. Application by TranQuoc Cuong and Khuc The Loc, as reported in SCMP 26 May 1990.

233. See Report of the Round Table on Solutions to the Problem of Refugees and the Protection of Refugees (San Remo, 12-14 July 1989) [hereafter: 1989 Round Table on Solutions]; see also, EXCOM Conclusion on Voluntary Repatriation No. 18 (XXI) 1980, regarded as reflecting international law and general international practice.

234. See Art. 13(2) UDHR; Art. 12 ICCPR; Art. 12(2) ACHPR; UN Sub-Commission of Prevention of Discrimination and Protection of Minorities Draft Declaration on the Right of Everyone to Leave any Country Including his Own and to Return to his Country, UN Doc. E/CN.4/Sub.2/ 1988/35 and annexes; Strassbourg Declaration on the Right to Leave and Return, adopted 9 May 1989; Principle 20, CSCE Final Act, Helsinki (1975); Vienna Follow-up Meeting (1989).

235. This element flows from basic international humanitarian principles of security and liberty and from the right of freedom of movement.

236. See, e.g., EXCOM, Note on International Protection, A/AC 96/694 (3 Aug. 1987), para. 50.

237. lbid. para. 51.

238. EXCOM, Note on International Protection, A/AC 96/660 (23 July 1985), para. 30. 
origin to readmit its national and to co-operate with the country of asylum in arranging for their safe return. ${ }^{239}$

Further guiding principles have been incorporated in the various studies and conclusions on voluntary repatriation regarding agreements for safe return, monitoring mechanisms and reintegration programmes. More specifically, recommendations have been made for the negotiation of written international repatriation agreements to be made available publicly and contain guarantees of safety, dignity and waiver of prosecution and persecution; ${ }^{40}$ the institution of effective international mechanisms for monitoring compliance with the terms of agreements (including recognition of UNHCR's legitimate role in this respect, which extends beyond the immediate moment of return, and facilitation of UNHCR's direct and unhindered access to returnees); ${ }^{241}$ and the establishment of reintegration projects to promote "durable re-insertion into the original community. ${ }^{242}$

It should be emphasised that the above principles, which stem from basic human rights of individuals, apply with equal force to the voluntary return of "rejected asylum-seekers."

Finally, of additional relevance is perhaps the right to compensation enjoyed by refugees. As propounded under the Draft Declaration of Principles of International on Compensation to Refugees and Countries of Asylum $^{244}$, "[s]ince refugees are, by definition forced directly or indirectly out of their country, they are deprived of the full and effective enjoyment of all articles in the Universal Declaration of Human Rights that presuppose a person's ability to live in his own country if he so chooses. Accordingly, the State that turns him into a refugee is in violation of all articles of the Declaration..." [Principle 3] and hence incurs an international obligation inter alia to pay compensation [Principle 6]. Indeed, "[t]he annual, near unanimous reaffirmations since 1948 of General Assembly Resolution 194(III) paragraph 11 of 1 December 1948, which grounds the right of refugees to compensation on 'principle of international law or... equity', have imbued this right with the quality of customary law... [Principle 7].

239. Loc.cit.

240. See 1989 Round Table on Solutions, supra n. 233 para. 52 and conclusion 17; see also 1989 CPA, supra n. 72, para $13(\mathrm{a})$.

241. 1989 Round Table on Solutions, supra n. 233, para. 51; 1985 Note on Protection, supra $n$. 238, conclusion 14; 1987 Note on Protection, supra n. 236, para. 55.

242. 1989 Round Table on Solutions, supra n. 233, conclusion 7.

243. See discussion in G.T.L. CoLES, Solutions to the Problems of Refugees and the Protection of Refugees, a Background Study (1989) [hereafter: Background study] at pp.318-322.

244. Adopted by the International Law Association at its 63rd Conference in Warsaw, 1988. 


\subsubsection{The British Position}

As one of the members of the Executive Committee of the High Commissioner of Refugees [EXCOM], the UK is presumed to have endorsed its conclusions pertaining to "voluntary repatriation." 245 it has thus recognised that voluntary repatriation generally constitutes the most appropriate solution to the refugee problem, that persons enjoy the right to return voluntarily to their country of origin, that repatriation of refugees should only take place at their freely expressed will and be carried out under conditions of absolute safety, preferably to the place of residence of the refugees in their country of origin.

In practice, however, the UK Government seems more concerned with numerical targets and, as declared with reference to Indo-Chinese asylumseekers, aims to ensure that "the rate of returns to Vietnam is sustained at 1,000 a month and that if there are fewer than 100 volunteers, the difference should be made up by non-volunteers. ${ }^{246}$

At the same time, on 12 October 1988 , the UK concluded an agreement with the Socialist Republic of Vietnam on the "phased return to Vietnam of those who have already applied to return. ${ }^{247}$ In addition, the British Government stated that "reintegration assistance is ... made available to help returnees settle back into their communities, with volunteers receiving slightly more generous terms. The Government is also considering financial support for NGO activities in areas of Vietnam from which boat people predominantly come. ${ }^{248}$ The UK has further undertaken in February 1990 to help fund a new transit centre in Hanoi to house an increased number of volunteers. ${ }^{249}$

Yet, as pointed out by critics the UK/SRV agreement fails to satisfy one of the primary conditions for repatriation consistent with international legal standards in that it does not contain a guarantee by the SRV that none of the individuals received back will be penalised for having left the country. ${ }^{250}$ In fact the Vietnamese Government announced at the time of the

245. See, e.g., Conclusion No. 18 (1980); Conclusion No. 40 (1985).

246. See observations by the Government on the Second Report of the Foreign Affairs Committee (23 May 1990) para. 34. See also statement by the [ex] British Foreign Minister, FrANCIS MAUDE, that " $t]$ he numbers who have gone back voluntarily are miniscule compared to the numbers who have come and it is clear that at the moment it is not solving the problem... we have to look at other means." Cited in F.MACMAHON, "Little Faith' in Voluntary Repatriation", SCMP 19 Sept. 1989.

247. See Joint Communique issued by the SRV, UK and HK Governments following the October talks, reproduced in IRAC Report, supra n. 23, Annex E.

248. Observations by the Government, supra n. 246, para. 36 .

249. See S. MACKLIN, “Hanoi, UK to Step up Returnees”, SCMP 22 Feb. 1990.

250. See IRAC Report, supra n. 23 at 80 et seq. 
agreement that only those returning who did not act against the Government would receive no more than a warning. ${ }^{251}$ By implication, returnees who are considered to have fled "with the intention of opposing the People's Government" or to have illegally organised or forced others to flee would be prosecuted and severely punished in accordance with the SRV Criminal Code. ${ }^{252}$

Nor does the repatriation agreement embody a waiver of persecution and discrimination or guarantees by the Vietnamese Government that returnees' civil rights be restored and their property recovered.

\subsubsection{Regional Attitudes}

Asian attitudes regarding repatriation - both voluntary and involuntary (and for that matter to the issues of "solutions" in general) are characterised by their inter-state, as distinct from human rights-based, orientations. ${ }^{253}$ The refugee problem is perceived as one drainage of national resources, social disruption and political instability, and solutions are sought in terms of shifting burdens.

Typical in this respect is the joint communiqué issued by the Foreign Ministers of the Association of Southeast Asian Nations (ASEAN) at their meeting in July 1990 grounding their call for repatriation of Indo-Chinese asylum-seekers on the "continuing influx [that] has imposed tremendous cost and created severe socio-economic, political and security problems for the countries of temporary refuge. ${ }^{n 254}$ The statement echoed the communiqué released at the Twelfth ASEAN Ministerial Meeting eleven years earlier (Bali, 30 June 1979) in which they "expressed grave concern over the deluge of illegal immigrants/displaced persons from Indochina which has reached crisis proportion and has caused severe political, socio-eco-

251. See D.WALLEN, "Hanol Vows not to Punish Boat People who Return", SCMP 11 Oct. 1988. 252. Articles 85 and 88 ; cited in IRAC Report, supra n. 23 at p.58. Note that the waiver from prosecution contained in the Memorandum of Understanding on the Principles and Procedures for Voluntary Repatriation concluded on 16 Dec. 1988 between the SRV and the UNHCR is confined to persons who have left the country without official permission (i.e. those violating Art. 89 - the least severe of the three SRV criminal measures relating to "illegal departures".

253. Contrast with regional attitudes as reflected in the Declaration and Concerted Plan of Action in Favour of Central American Refugees, Returnees and Displaced Persons, adopted by the International Conference on Central American Refugees (CIREFCA), UNDoc.CIREFCA/89/ 14 (31 May 1989), e.g., Section II, Part One, C13(c): "The Problems of refugees, returnees and displaced persons and the proposals for solutions should continue to be treated on a strictly humanitarian and non-political basis; in this context, States are guided above all by considerations of solidarity with the individuals in need and the importance of identifying humane solutions to their problems, giving priority to the preservation of life and personal safety above any other consideration."

254. Cited in the Report "US Criticised over Viets", SCMP 29 July 1990. 
nomic and security problems in ASEAN countries and will have a destabilising effect the region." 255

Emphasis on "burden borne" is invariably combined in the respective statements with demands for burden-sharing in accordance with the relevant apportionment of responsibility. Repatriation is thus viewed as an element of discharge of obligation by the State of origin bearing responsibility for the "root conditions" which caused its citizens to flee.

Such was also the approach taken by the Asian-African Legal Consultative Committee in its 1985 study of "Status and Treatment of Refugees" which dealt with voluntary repatriation in a section entitled "Principles of State Responsibility. ${ }^{\text {257 }}$

Although supporting in principle voluntary repatriation as a "durable solution", the region's representatives to the 1989 Geneva conference who urged "a swift and final solution" to the problem ${ }^{258}$ appear to consider the involuntary repatriation of asylum-seekers determined not to be refugees as more expedient

\subsubsection{The Hong Kong Approach}

Although the Hong Kong Government's efforts to find "solutions" to the refugee problem have been primarily directed towards mandatory repatriation of non-refugees, it has declared its "full" and "wholehearted" support for voluntary returns. ${ }^{259}$ Furthermore, the Government considers repatriation on a voluntary basis an inadequate measure on its own to resolve the issue of the large number of non-refugees already in the territory and as a

255. Cited in: Study on Human Rights and Massive Exoduses (Report by SADRUDDIN AGA KHAN, Special Rapporteur, 38 UN ECOSOC Off. Rec., Commission on Human Rights (UNDoc.E/CN.4/ 1503 Annex 11) at p.19 (1981).

256. See summary of "perspectives" evident among the participants of the [1989] Geneva Conference in M. KNowLEs, "The International Conference on Indochinese Refugees and its Aftermath", Refugee Policy Group issue brief (Aug. 1989).

257. The paper is discussed in Coles, Background Study, supra n. 243 at pp. $278-281$.

258. KNOWLES, supra n. 256 at p.2.

259. See Secretary for Security's speech, Leg.Co Proc 29 Nov. 1989 at p.495. Note, however, the scathing comments by legislative Councillors describing voluntary repatriation as "ridiculous, if not deliberately contrived as a joke" ("As we are all aware, there was no way of escaping Vietnam without having to go through a lot of hardships on the rough seas, and risking one's life in the process. Unless there are special compelling reasons, it is inconceivable that they would volunteer to go home just like that") [per Miss LEUNG] LegCo Proc 29 Nov. 1989 at p.480. A recurrent theme among the Counsellors who seek a "permanent end" or an "ultimate solution" to the problem is the ineffectiveness of voluntary repatriation as a deterrent: "Not only do they know that they will not be rejected by that even though they may be determined to be non-refugees, they have no fear of leaving unless they volunteered. For many of the Vietnamese boat people, so long as they need not leave, so long would they continue to believe, however erroneaously, that there is hope to move to the West where the moon is large and brighter..." [per Mr. LAM] ibid., at p. 478. 
means of deterring new arrivals. ${ }^{260}$ The local authorities therefore have endorsed both modes - voluntary and involuntary - of return to Vietnam which are viewed as "being complementary and perfectly capable of operating alongside each other. ${ }^{261}$

Indeed, the Hong Kong Government "helped to engineer" ${ }^{262}$ a voluntary repatriation programme based on the UK/SRV agreement of 12 October $1988^{263}$ and in conjunction with the UNHCR/SRV Memorandum of Understanding of 16 December $1988 .^{264}$

Notwithstanding the relative success of the programme, ${ }^{265}$ observers have questioned its "voluntary" nature ${ }^{266}$ and have expressed concerns about the failure of institutional safeguards to satisfy with international norms. ${ }^{267}$

\subsection{Mandatory Repatriation}

\subsubsection{International Rules}

The fundamental rule applicable to the issue of mandatory repatriation is non-refoulement, the status of which as a norm of customary international law is highlighted elsewhere in this paper. We also discussed the legal duty embodied in the rule to permit entry to asylum-seekers at least for the purpose of temporary refuge. In this section, emphasis is placed on the "no return, no expulsion" aspect of non-refoulement, proscribing the return or expulsion of asylum-seekers to the country where his/her life or freedom is threatened on account of specific circumstances.

260. Ibid. at p. 495 .

261. LegCo Proc 25 Oct. 1989 at p.97.

262. LegCo Proc 29 Nov. 1989 at p.495.

263. Supra n. 247.

264. Supra n. 252.

265. Over 4,000 asylum-seekers have returned to Vietnam under the programme, compared to very few from other countries in the region.

266. See D.Gallagher, The Second International Conference on Indochinese Refugees: A New Humanitarian Consensus? (Refugee Policy Group, May 1989) at p.28: "If persons choose to return only when faced with indefinite detention in prison-like conditions, the term "voluntary repatriation' cannot be used with much of a sense of integrity." See also Women's Commission Report, supra n. 299 , at p.22.

267. See critique discussed supra in text corresponding to notes 250-252. Note, however, press release issued by UNHCR in Hong Kong on 20 March 1989 stating that "UNHCR is already engaged in an active process of monitoring voluntary returnees to Vietnam. It has every reason to be satisfied that the guarantees provided for those returning under the voluntary programme are being fully respected. In the very few instances in which reports to the contrary have been received, UNHCR has engaged the full co-operation of the Vietnamese authorities in looking into them and has discovered them to be unfounded. UNHCR and the Government of Vietnam remain fully committed to continue co-operation in this monitoring exercise and in the voluntary return programme as a whole. 
Additional attention is accorded here to questions pertaining to the range of application of the non-refoulement obligation, in particular its extension to cover persons who do not necessarily meet "convention refugee criteria." The support in international instruments and State practice for a broad application of non-refoulement is well documented. ${ }^{268}$ Evidence includes the 1967 Declaration on Territorial Asylum which provides: "[N]o person [who invokes the right to seek and enjoy asylum from persecution] shall be subjected to... rejection at the frontier or, if he has already entered the territory in which he seeks asylum, expulsion or compulsory return to any state where he may be subjected to persecution; ${ }^{269}$ reaffirmations by UNHCR of the application of non-refoulement to all persons within its extended competence, persons not only in fear of persecution but also in "serious danger resulting from unsettled conditions of civil strife; ${ }^{270}$ the recognition in regional treaties and declarations of a wider category of persons compelled to flee their countries because of acts of external aggression, events seriously disturbing public order, generalised violence, internal conflicts or massive violations of human rights to whom protection of non-refoulement is owed; ${ }^{271}$ and practices of states of granting non-refoulement to "non-convention refugees" such as US" "extended voluntary departure", Canada's "designated classes and special measures programmes", the UK's "exceptional admissions" or the Australian permits on "strong compassionate and humanitarian grounds." 272 To the examples of positive state practice, one should also add the denunciation by states of the breach of the norm. ${ }^{273}$

In fact, the application of principle of non-refoulement is "independent of any formal determination of refugee status by a state or an international organisation. Non-refoulement is applicable as soon as certain objective conditions occur. ${ }^{274}$ An obligation is imposed on the receiving party on the basis of the objective need faced by the victim.

The general nature of the non-refoulement prohibition is also reinforced by another fundamental norm of customary international law, namely the

268. See IRAC Report, supra n. 23 at pp.72-78.

269. Cited ibid. at p.73.

270. Cited ibid. at p.74.

271. Cited ibid. at p.75.

272. Cited ibid. at pp.75-77.

273. Such as following Hong Kong's act of repatriation of 51 asylum-seekers on 12 Dec. 1989. See P.BOWERING \& E.LAU, "Furore over Forced Repatriation of Viets", FEER 21 Dec. 1989 at pp.13-14.

274. G.GoodWIN-GILL, "Non-refoulement and the New Asylum-Seekers", 26 Virg. JIL (1986) p.897 at p.902 and references cited therein. See also UNHCR Report, UNDoc.E/1985/62 (1985) paras 22-23, stating that non-refoulement" should be acknowledged and observed as a rule of jus cogens even absent a finding that a person is a convention refugee." 
rule against torture. As stipulated in the 1984 Convention Against Torture and Other Cruel, Inhuman or Degrading Treatment or Punishment, "no State Party shall expel, return ('refouler') or extradite a person to another State where there are substantial grounds for believing that he would be in danger of being subjected to torture" [Article 3]. Indeed, the act of "refoulement' in such circumstances was held to constitute itself a violation of the rule prohibiting inhuman or degrading treatment or punishment under the European Convention on Human Rights. ${ }^{275}$ A Contracting State is thus considered to have an indirect responsibility to guarantee that the individual will not be subjected to torture and inhuman measures upon return. It is the threat not the fact of torture or related treatment, which identifies a person as an actual or potential victim.

\subsubsection{The British Position}

The British obligation of non-refoulement under the Refugee Convention is given statutory expression in the Statement of Changes in Immigration Rules. ${ }^{276}$ A general clause [para. 153] in the section covering "deportation" sets out the special position of refugees in that "[w]here a person is a refugee full account is to be taken of the provisions of the Convention and Protocol relating to the Status of Refugees." Also contained therein is a guidance to the interpretation of the Immigration Rules which are not to be construed as requiring action contrary to the UK's obligations under the Refugee Convention.

A more specific rule is incorporated in Paragraph 165 which stipulates that "[i]n accordance with the provisions of the Convention and Protocol relating to the Status of Refugees, a deportation order will not be made if the only country to which he can be removed is one to which he is unwilling to go owing to well-founded fear of being persecuted for reasons of race, religion, nationality, membership of a particular group or political opinion."

Yet, "full account" of the Refugee Convention and Protocol is to be taken "where a person is a refugee" [emphasis added]. Arguably, the efficacy of the non-refoulement proscription embodied in the Immigration Rules is undermined given the discretion vested in non-expert border officials to determine prima facie validity of a refugee claim and, after minimal consultation, to return aliens whose claims are manifestly unfounded in the official's opinion. Although Paragraph 73 of the Immigration rules instructs an

275. See Amekrane Case, 16 YBECHR (1973) p.356 (Decn admiss, Report of the Commission, adopted 19 July 1974).

276. Supra n. 13. 
immigration officer to refer possible refugee cases to the Home Office for decision, the difficulty of policing aliens' applications at the border and the virtual impossibility of discovering violations through returned aliens may reduce the utility of these directives.

Apart from the possibility of instances of non-refoulement at the border, a potential for violations of non-refoulement also exists given the lack of a right of appeal from within the UK against a negative determination of a claim to refugee status (and hence against removal as an illegal entrant).

Be that as it may, as noted earlier, persons denied Convention recognition for failure to meet the technical requirements of the definition are nonetheless frequently granted asylum and consequently are protected from "refoulement" (although not necessarily vested with various substantive rights accorded Convention refugees). Additionally, persons denied both refugee status and asylum are occasionally allowed to remain, and are thus shielded from "refoulement" at least for the duration of the permit.

Special policy considerations - which are not necessarily articulated in the context of non-refoulement - seem to affect however the British Government's approach to mandatory repatriation of Vietnamese asylumseekers from Hong Kong. As reflected in the "Observation by the Government on the Second Report of the Foreign Affairs Committee ${ }^{\text {2277 }}$, purely pragmatic factors underlie the decisions adopted in this regard. The Government shares the FAC's view that "in the absence of significant levels of voluntary repatriation, there is no alternative to the repatriation of those who are screened out" [para 32] and states openly that its "objective... [is] to ensure that the rate of returns to Vietnam is sustained at 1,000 a month and that if there are fewer than 1,000 volunteers, the difference should be made up by non-volunteers" [para 34].

The mandatory repatriation of 51 Vietnamese boat people who were screened out by the Hong Kong authorities was justified by the British Government with reference to the facts that (a) "[n]o force was used;" (b) it was carried out "under a bilateral agreement reached with the Vietnamese Government in June 1989 which guaranteed that returnees would not be punished by the Vietnamese authorities"; and (c) "[t]wo former Ministers... visited Vietnam in January and confirmed that no force had been used against those returned and that they had not been ill-treated in any way." 278

277. Supra n. 246.

278. Ibid. para 32. 


\subsubsection{Regional Attitudes}

Notwithstanding the various degrees of compassion displayed by the first asylum countries in Asia, they have presented a united front on the issue of mandatory repatriation of boat people who have been "screened out $^{n}$ as non-refugees. ${ }^{279}$

Viewing the refugee problem in general as one of illegal migration, the Southeast Asian nations seek solutions within corresponding norms, including the rules of State [of origin] responsibility. They further rely for support on the Comprehensive Plan of Action agreed upon at the 1989 International Conference on Indo-Chinese Refugees which provided that "persons determined not to be refugees should return to their country of origin in accordance with international practices reflecting the responsibilities of States towards their own citizens" [Article 12].

The region's protagonists appear to overlook, however, the prerequisites implied under the CPA, namely the establishment of guarantees and diplomatic arrangements necessary to ensure the safe deportation of nonrefugees to Vietnam. ${ }^{280}$

\subsubsection{The Hong Kong Approach}

Unlike its British counterpart, Hong Kong's law does not contain a formal codification of the principle of non-refoulement. While as a rule of customary international law non-refoulement has arguably the force of law in the territory through the common law, its incorporation is nonetheless contingent on the absence of clear legislation to the contrary.

Such a potentially inconsistent provision may be contained in Hong Kong's Immigration Ordinance. Specifically, under Section 13E of the Ordinance, the Director of Immigration is authorised to order "at any time" the removal from the territory of any Vietnamese refugee or person detained in Hong Kong under Section 13D (i.e. a detained person awaiting a decision to allow him of her to remain in the territory as a refugee, or a detained person who was refused such permission). No legislative constraints are imposed on the Director's exercise of discretion and no allowance made for considerations of personal circumstances or for the possibility of risk to life or ill-treatment which refugees may encounter if expelled to their country of origin.

279. See F.MACMAHON, “United Call to Return Vietnamese”, SCMP 17 May 1990.

280. At present there are no formal repatriation arrangements between Vietnam and the ASEAN countries, although discussions on the matter have taken place within Thailand, Malaysia and the Philippines. 
Nor are refugees granted a right of appeal against removal orders and are unlikely to be able to avail themselves of the general appeal provisions in the Immigration Ordinance which are limited to persons who have the "right to land in Hong Kong" or the permission of the Director of Immigration to remain in Hong Kong [s. 53A]. Refugees faced with removal from Hong Kong also cannot rely on the International Covenant of Civil and Political Rights applicable in Hong Kong given the UK's reservation regarding the application of Article 13 "in so far as it confers a right of review of a decision to deport an alien and a right to be represented for this purpose before the competent court. ${ }^{\text {281 }}$

The Hong Kong Government could have thus invoked Section 13E to justify the "legality" under domestic law of the forced repatriation to Vietnam on 12 December 1989 of 51 "screened out" asylum-seekers. ${ }^{282}$ In fact, the Government appears to claim in respect to those determined not to be refugees under the local screening process the power generally available vis-à-vis illegal immigrants. ${ }^{283}$

Not that any justification was demanded domestically. The Government has the overwhelming support of legislators ${ }^{284}$, the Hong Kong people $^{285}$ as well as the PRC Government ${ }^{286}$ for a vigorous programme of mandatory repatriation.

In order to minimize international criticism, however, several points have been raised in defence of the policy. It has thus been portrayed as fully consistent with the Comprehensive Plan of Action endorsed in Geneva - indeed, "an intrinsic and logical part of it. ${ }^{\text {287 }}$ The Government has also emphasised that similar provisions to those applicable to voluntary returnees have been made - including arrangements for reintegration assis-

281. At present there are no formal repatriation arrangements between Vietnam and the ASEAN countries, although discussions on the matter have taken place within Thailand, Malaysia and the Philippines.

282. It may be interesting to note that when proposing the introduction of Section $13 \mathrm{E}$ into local legislation, the Secretary for Security expressly declared that it "provides additional legal powers to repatriate any refugee if and when circumstances permit." LegCo Proc 30 June 1982 at p.1084.

283. Secretary for Security: “...we are fully supported by Her Majesty's Government who see the return of non-refugees to their country of origin as being in the same category as the deportation of illegal immigrants anywhere else in the world." LegCo Proc 29 Nov. 1989 at p.495.

284. See Leg.Co debate on the motion urging the British Government to "secure as soon as possible... the urgent mandatory repatriation from Hong Kong to Vietnam of all Vietnamese boat people classified as non-relugees on 29 Nov. 1989 - All members with the exception of 2 (and 2 absentions) voted in support of the motion.

285. See supra ns. 37 and 38.

286. See C:YeUng, "Force Viets Home Soon, Says Zhou”, SCMP 5 May 1990. Note also reports that the PRC sent back to Vietnam more than 77,000 Vietnamese boat people who tried to make their way to Hong Kong via China -F. WoNG, "China Sent Back 77,000 Vietnamese", SCMP 1 Mar. 1990.

287. LegCo Proc 8 Nov. 1989 at p.337; LegCo Proc 29 Nov. 1989 at p.495. 
tance, monitoring and assurances of non-persecution - and more specifically that "there was no evidence of any political persecution or official harassment of the 51 who were returned to Vietnam in December. ${ }^{288}$

Some critical observation are nonetheless warranted. Firstly, a repatriation of asylum-seekers as envisaged under the CPA is premised on the establishment of a fair refugee status determination process. We noted elsewhere in this paper ${ }^{289}$ that doubts persist with respect to the fairness of the screening process in Hong Kong and that it could not, therefore, be relied upon to identify all those who would be at risk of human rights violations if returned to Vietnam.

Secondly, the assurances said to have been provided by the Vietnamese authorities fall short of required guarantees for safe return. ${ }^{290}$ Vietnam has not revoked its laws against unauthorised departure and has signed no international agreement for the withholding of punishment from involuntary (as distinct from voluntary) returnees. In fact, Vietnam's Foreign Minister is reported to have warned that Vietnam could not be held responsible for boat people who do not volunteer to return from Hong Kong. ${ }^{291}$ Nor has an effective system for monitoring returnees over a period of time been established and occasional visits by members of Parliament or diplomatic staff are not a viable substitute for such a system.

Thirdly, concerns over the safety of returnees have been raised in view of continued human rights abuses in Vietnam ${ }^{292}$, the harsh treatment of people caught trying to leave that country ${ }^{293}$ and recent acts by the Vietnamese Government to "suppress dissent." 294

288. LegCo Proc 17 Jan. 1990.

289. See supra ns. 98-106 and 153-172 and corresponding texts.

290. See discussion supra in text corresponding to ns. 250-252.

291. See S:MACKLIN, "Vietnam Refuses Responsibility for Forced Return, SCMP 26 Feb. 1990.

292. See F.MacmaHon, "Human Rights Abuses 'Continue in Vietnam", SCMP 21 Feb. 1990, citing Amnesty International's report on "Vietnam: 'Renovation (Doi Moi), the Law and Human Rights in the $1980 \mathrm{~s}^{n}$.

293. Imprisonment or detention without trial in reeducation camps from between six months and two years. See S. GREEN, "Finding Reasons to Flee", SCMP 21 Feb. 1990, citing Amnesty's report, ibid.

294. See, Hong Kong Protection of Vietnamese Asylum Seekers: Developments Since December 1989, (Amnesty International, mimeographed, 11 July 1990) at pp.11-12: It is suggested that “...some asylum-seekers, if returned to Vietnam, could face possible detention as priosners of conscience, including those who were formerly reeducation detainees or who served in the administration of the former South Vietnamese Government, as well as people whose religious, literary or other activities are unacceptable to Vietnam Government. 


\subsection{Resettlement in Third Country}

\subsubsection{International Rules}

While no enforceable right to be resettled is recognised under international law, general principles grounded on the norm of international solidarity and burden-sharing have been invoked to support demands for resettlement by third countries, reflecting the perception of the refugee problem as one affecting the international community as a whole.

Reference is made in particular to the duty prescribed under the Declaration on Principles of International Law Concerning Friendly Relations and Co-operation Among States in Accordance with the Charter of the UN to "co-operate in the promotion of universal respect for and observance of human rights and fundamental freedoms for all and in the elimination of all forms of racial discrimination and all forms of religious intolerance. ${ }^{295}$ It is emphasised that this duty "was the more compelling where human rights violations led to refugee outflows and their adverse consequences for other countries. ${ }^{296}$

In the context of international refugee law, a general approval has been expressed for the establishment - along lines agreed upon by members of $\mathrm{EXCOM}^{297}$ - of effective burden-sharing arrangements for assisting countries which receive large numbers of asylum-seekers, including the provision of "resettlement possibilities in third countries." That legitimate expectations have been created for third party contributions is clearly reflected in the Comprehensive Plan of Action endorsed at the June 1989 Conference on Indo-Chinese Refugees calling the international community to "respond to the need for resettlement, in particular through the participation by an expanded number of states" as well as a multi-year commitment to resettle all the Vietnamese who have arrived in temporary asylum camps prior to an agreed date" [Article 9]. ${ }^{298}$

In fact, notwithstanding the absence of strong legal commitments on their part, developed countries have assumed responsibility for resettlement of refugees granted temporary refuge by countries of first asylum. ${ }^{299}$ Such a commitment, moreover, has been viewed as a "vital component" of

295. GA Res.2625(XXV) of 24 Oct. 1970.

296. Round Table on Solutions, supra n. 233 at p.7.

297. See Conclusion on the Protection of Asylum-Seekers in Situations of Large-scale Influx, adopted by EXCOM at its 32nd Session, 12-21 Oct. 1981, A/AC.96/601 at pp.15-18.

298. Supra n. 72.

299. Over 1.5 million refugees from Indo-China have been resettled in other countries since the fall of Saigon in 1975 - per British Secretary's speech to the Geneva Conference, repr. in SCMP 14 June 1989. 
any comprehensive plan of action aimed at solving the refugee problem. 300

Resettlement by third countries finds its normative basis also in other principles recognised by international law, such as "rescue at sea" and "family reunification." Thus, in connection with the universally accepted obligation to rescue any person in distress at sea ${ }^{301}$, a practice of flag state responsibility for resettlement has developed in the South East Asian region. ${ }^{302}$ Such responsibility has nonetheless been modified to allow more equitable burden-sharing through the establishment in 1980 of DISERO (Disembarkation Resettlement Offers) ${ }^{303}$ and a complementary scheme, RASRO (Rescue at Sea Resettlement Offers) ${ }^{304}$ in 1985.

The principle of family reunification is well recognised ${ }^{305}$ and underlies many resettlement programmes. In the absence, however, of a generally accepted definition of the "family", states' policies and practices tend to vary, sharing nevertheless a trend of restrictive application of the concept in matters of immigration. ${ }^{306}$

300. Article 8, CPA, supra n. 72.

301. See 1910 Brussels Convention for the Unification of Certain Rules of Law Relating to Assistance and Salvage at Sea, Art. 11; 1914 Convention for the Safety of Life at Sea, Art. 13; 1958 Geneva Convention on the High Seas, Art. 12(1); 1960 Convention on Safety of Life at Sea, Ch. V, Rg. $15 ; 1982$ Convention on the Law of the Sea, Art. 98. For specific application to refugees, see 1979 International Convention on Maritime Search and Rescue, Annex 2.1.10, 5.3.3 (8).

302. It has been observed, however, that such a practice was "based more on the practical difficulties in coping with mass influx of asylum-seekers faced by coastal states in that area than on legal principles" (as the ship does not constitute part of the flag state's territory and the latter cannot be deemed the country of first refuge for the purpose of the Refugee Convention). See Note "Rescue at Sea", Yearbook 1984 (International Institute of Humanitarian Law) 108 , at p.111.

303. A pool of resettlement offers to be utilised where a flag state could not provide the required resettlement guarantee.

304. A pool of resettlement places contributed according to a fixed criteria by any state wishing to participate, allowing flag states to confine admissions for resettlement to their contributions irrespective of number of persons rescued (as long as places remain available in the pool).

305. For a specific link between family rights and migration, see 1975 Final Act of the Conference on Security and Co-operation in Europe (Helsinki Accord): Sub-section (b) - "Reunification of Families" - in the section on Human Contacts provides: "The participating States shall deal in a positive and humanitarian spirit with the applications of persons who wish to be reunited with members of their family. The Final Act of 1951 Refugee Conference contained a recommendation stating: "The Conference, Considering that the unity of the family, the national and fundamental group unit of society, is a essential right of the refugee, and that such unity is constantly threatened, and Noting with satisfaction that ...the rights granted to a refugee are extended to members of his family; Recommends Governments to take the necessary measures for the protection of refugee's family, with a view to (i) that the unity of the refugee's family is maintained particularly in cases where the head of the family has fulfilled the necessary conditions for admission to a particular country; (ii) the protection of who are minors, in particular unaccompanied children and girls, with special reference to guardianship and adoption." See also EXCOM Conclusion on Family Reunion adopted in its 28th Session 1972 and the "Body of Principles for Procedures on the Reunification of Familes", adopted on 27 Jan. 1980 by the Council of the International Institute of Humanitarian Law. 


\subsubsection{The British Position}

Three main principles determine British resettlement policies: a) response to a specific international crisis; b) ship rescues; and c) family reunions.

Thus, in the context of the refugee crisis following the fall of Saigon in 1975, the British Government authorised the entry of 300 Indo-Chinese who "had connections with the UN. ${ }^{\mathbf{m} 307}$ In 1976, in response to international appeal by the UNHCR, the UK accepted 116 "people who had left Vietnam in small boats. ${ }^{308}$ The quota was increased in January 1979 to 1500 and at the 1979 July Conference on Indo-Chinese Refugees, the UK pledged 10,000 resettlement places. ${ }^{309}$ Five hundred places were allocated in May 1987 to be filled within two years, 1,000 more were announced in early $1989^{310}$ and the recent 1989 Conference resulted in an additional promise to take 1,000 refugees. ${ }^{311}$

Resettlement in the UK of Indo-Chinese asylum-seekers rescued at sea by British ships also originated in specific circumstances, when in mid1979 South East Asian countries bordering the China Sea refused to allow disembarkation of refugees in the absence of guarantees of resettlement by the country of registration of the vessel. In January 1978 the UK Government agreed that "where required to allow their disembarkation, an undertaking would normally be given to accept refugees rescued by UK registered ships for resettlement [in Britain] if no other country had agreed to do so within a period of 90 days. ${ }^{312}$

Its practical origin notwithstanding, a continued ${ }^{313}$ commitment to provide resettlement guarantees has been justified also in humanitarian terms as designed "[to assist] the masters of British ships to fulfill their obligations towards those at risk at sea by facilitating their disembarkation at the first port of call. ${ }^{\text {314 }}$

306. See Round Table of a Group of Experts on the Reunification of Familes, Florence 4-6 Dec. 1986. Conclusions, reproduced in International Institute of Humanitarian Law, Yearbook 1986-87 at p.323 (urging States to adopt a flexible approach which takes account of cultural and social factors).

307. See Memorandum of the Home Office on "Admission and Settlement of Refugees from Vietnam", submitted as evidence to the Home Affairs Sub-Committee on Race Relations and Immigration (SCORRD) [hereafter: Home Office Memorandum], supra n. 200 at p.88.

308. Loc cit.

309. Loc cit.

310. See D.WALLEN, “UK Will Accept a Further Quota of Refugees", SCMP 10 June 1989.

311. Foreign Secretary's speech, repr, in SCMP 14 June 1990 at p.23.

312. Home Office Memorandum, supra n. 307 at p.88.

313. The UK has also agreed in July 1985 to join the RASRO scheme, ibid. at p.89.

314. Loc cit. 
The third source of asylum-seekers accepted for resettlement in the UK are family reunion cases. Yet, although initially "when the number of refugees entering the UK was small, the criteria for admission of their relatives (mainly in Vietnam) were widely drawn: spouses, unmarried children under 21, parents, and unmarried brothers and sisters were admitted. However, following the completion of the 10,000 quota it was decided that given the "UK's wide ranging commitments towards refugees of many nationalities, it was not appropriate to maintain more generous criteria for the dependants of Vietnamese refugees. Accordingly, since May 1981 the same criteria have been applied to Vietnamese family reunion cases as to those involving refugees of other nationalities. ${ }^{\text {"315 }}$

In fact, admission of family members of refugees is governed under the Immigration Rules and general immigration control considerations are applied. ${ }^{316}$ Such an "interlocking of immigration policy and refugee policy" has attracted harsh criticism of relief and welfare agencies especially in the light of an alleged "racially unequal immigration policy" and related public attitudes to immigrants. ${ }^{317}$

Generally, it is evident that resettlement of refugees in the UK is not endorsed by the Government as a "solution" to the refugee problem. The reasons stated by officials are that "to transfer refugees with their own strong cultural tradition to unfamiliar and remote industrialised countries does not always provide a satisfactory answer" and that resettlement may undermine the more appropriate "regional political solutions. ${ }^{n 318}$ The difficulties of refugees in adapting to life in the UK have also been used by the British Government as an argument to reject requests for an increased intake from Hong Kong camps based on the UK's responsibility for Hong Kong as a dependent territory. ${ }^{319}$ It way nonetheless be noted that the Home Office has succumbed to pressure to expand the existing criteria of resettlement to allow consideration for admission of refugees whom the Hong Kong Immigration Department regards as "able to adequately support themselves in the UK and who desire to be settled there. ${ }^{320}$

315. Ibid. at pp.89-90.

316. See, however, recommendation by SCORRI for relaxation of family reunion criteria in respect of Vietnamese in camps in countries of temporary asylum. SCORRI Report, supra n. 200, paras 11-17.

317. See Memorandum Submitted by the Joint Council for the Welfare of Immigrants, Appendix to minutes of evidence, SCORRI Report, supra n. 200 at pp.209-210: "We fear that the British Government's reluctance to admit more Vietnamese refugees here from Hong Kong camps has nothing to do with refugee policy as such, but everything to do with attitudes towards Asian immigration. A good refugee policy must be free of racial discrimination and based rather on need."

318. FCO Memorandum, SCORRI Report, supra n. 300 at p.127.

319. Ibid. at pp.129-131.

320. See F.MACMAHON, “UK Revises Criteria on Resettlement”, SCMP 24 Apr. 1990. 


\subsubsection{Regional Attitudes}

In parallel to their "apportion of responsibility" approach, countries in the region have consistently maintained that only two "solutions" to the refugee problem are viable - repatriation to the country of origin and resettlement in the West. Such a stance was taken in 1979 when in a joint communiqué ASEAN Foreign Ministers asserted that any illegal immigrants leaving Indo-China remained the responsibility of their country of origin which must accept them back and urged resettlement countries to give definite commitments to increase their intake. ${ }^{321}$ A similar position was presented ten years later by ASEAN representatives to the 1989 Conference who reiterated their expectation that all asylum-seekers would eventually either be resettled outside the region or returned to their country of origin.

\subsubsection{The Hong Kong Approach}

Resettlement in third countries, which used to be regarded by Hong Kong authorities as the only realistic alternative available for asylum-seekers residing in local camps, is now viewed as a "one-off" solution for the $10,091^{322}$ persons with recognised refugee status currently in Hong Kong.

The Government generally considers the CPA as offering the "best prospect for an overall solution to the Vietnamese boat people problem. ${ }^{323}$ It consequently relies - for the clearing of the backlog of Vietnamese refugees who arrived in the territory before the cutoff date of 16 June 1988 as well as others determined to be "genuine refugees" - on resettlement pledges made at the Geneva Conference and the agreement reached on relaxation of resettlement criteria of refugees. 324

Resettlement, however, is not regarded as an option open to those "screened out", who constitute the bulk of the camp population ${ }^{325}$ and whom the Hong Kong authorities seek to repatriate - voluntarily or involuntarily - to Vietnam. . $^{326}$

321. Supra n. 325.

322. Figure quoted in S.MACKLIN, "Twice as many Vietnamese Leaving Hong Kong as Arriving", SCMP 15 July 1990.

323. LegCo Proc 25 Oct. 1989 at p.96.

324. LegCo Proc 29 Nov. 1989 at p.495.

325. 47,112 in July, figure quoted in MACKLN, supra n. 322.

326. LegCo Proc 29 Nov. at p. 495. 


\subsection{Local Integration}

\subsection{International Rules}

Since solutions are to be linked with the rights of the individual refugee, the frame of reference of "integration" ought to be located within human rights law. 327

Accordingly, local integration (and, for that matter, settlement in a third country) is accomplished when the refugee has achieved not merely physical settlement but also the "possession or enjoyment of all normal rights of settlement, including finally those in relation to nationality. ${ }^{n 328}$ Furthermore, integration as a solution to the refugee problem of loss of a community means "legal integration" (full participation in political, social, economic and cultural activities as a matter of right) as well as "economic integration" and "self-sufficiency. ${ }^{\text {"329 }}$

\subsubsection{The British Position}

Notwithstanding elaborate reception and settlement programmes ${ }^{330}$ covering essential needs of refugees such as housing, education, employment and health - observers note the insecure status of refugees "admitted for permanent resettlement" due to the temporary nature of their admission permit (subject to short term renewals). ${ }^{331}$

Specific disadvantages have been identified, including the "difficulty, arising from their temporary status, in obtaining work, housing and credit; difficulty of obtaining funds from the DHSS [Department of Health and Social Services] in spite of real need, and the fact that any children born to them while they are on time-conditions will be born without British citizenship." ${ }^{332}$

327. For a thorough discussion of the human-rights approach to solutions in general and on the specific concept of integration in such a context, see G. ColES, Background Study, supra n. 243 at pp.274-5; 284-304; see also Round Table on Solutions, supra n. 233 at pp.4-5.

328. Round Table on Solutions, supra n. 233 at p.4.

329. Ibid. at pp. 5,8

330. See Home Office memorandum, supra n. 307 at pp.91-105.

331. See Memorandum of Joint Council for the Welfare of Immigrants, supra n. 317 at p.208.

332. Loc cit. Note that under section 1 of the 1981 British Nationality Act, where refugee parents are legally stateless, the child will be stateless. Where the parents have a legal nationality, and are able theoretically under the law of the country of irigin to transmit that nationality to a child born in the UK, it will probably be the case, in practical terms, that the whild will be unable to obtain its rights from the parents' country. 


\subsubsection{Regional Attitudes}

Generally, "local integration" as a durable solution is not espoused by the Asia's first asylum countries. Indonesian authorities have claimed that "as a matter of policy, Indonesia is not in a position to accept Indochinese refugees for permanent resettlement, because of its heavy burden in caring for its own people. ${ }^{333}$ Malaysia is unwilling to admit any Vietnamese for permanent residence because of its "delicate racial balance" although it had accepted over the last decade some 9000 Cham.Burmese and Khmer Muslims for resettlement in Malaysia. ${ }^{334}$ (These persons received language, cultural and religious training from a voluntary Islamic Missionary and welfare agency and became eligible for permanent residence with all rights of non-citizen aliens, including the grant of Malaysian citizenship to their locally born children). Philippine Government officials have declared that "as a matter of policy the Philippine Government does not accept refugees. Beset as it is by the attendant problems of a Third World country attempting to move forward and the high expectations of its people for a better life, the Philippines cannot afford to open its doors to refugees for resettlement. ${ }^{{ }^{335}}$ No settlement - permanent or otherwise - is available to refugees in Singapore. In accordance with its immigration law, Thailand does not consider for permanent residence any person who enters the Kingdom without a visa, thus practically excluding all asylum-seekers and displaced persons (although exceptional permissions may be extended to persons with ethnic links to Thailand as determined under the Thai Nationality Act). ${ }^{336}$

Standing alone in this respect is the People's Republic of China which granted permanent resettlement (mostly on State farms in Southern China) to some 252,000 from Indo-China (90\% of whom were ethnic Chinese) in the late 1970s. Few of these "settlers" have opted for citizenship but all enjoy the same rights and Government services as citizens. ${ }^{337}$ It may be noted, however, that about one-third of the Indo-Chinese refugees are "not fully economically self-sufficient ${ }^{\mathbf{n} 38}$, as is well attested by continuous attempts by "ex-Vietnamese refugees" to enter Hong Kong. ${ }^{339}$

333. See SoEroso, supra n. 21 at p.118.

334. See World Refugee Report, supra n.23 at p.40.

335. See MonTES, supra n. 21 at p.161.

336. See MUNTARBHORN, supra n.21 at pp.169-171.

337. See World Refugee Report, supra n. 23 at p.36.

338. Loc cit.

339. They are nonetheless considered, both by Chinese and Hong Kong authorities, to be illegal immigrants and are repatriated accordingly. 


\subsubsection{The Hong Kong Approach}

While Hong Kong regards itself primarily as a "country of first asylum", it has accepted for permanent settlement some 14,500 refugees and displaced persons from Indo-China since 1975. About 600 Vietnamese refugees from both local and overseas centres have also been granted permission to join their relatives in Hong Kong under a family resettlement scheme. In addition, as part of a move aimed at encouraging other countries to increase their intake from the territory, the Hong Kong Government, acting on the recommendation of the British Foreign and Commonwealth Office, has approved in April 1986 the absorption of 150 refugees (at a rate of 20 per month) who are able to comply with the following requirements: (a) They would be long-stayers, i.e. must have been here since before July 1982; (b) should be ethnic Chinese; (c) should be financially independent (i.e. capable and supporting themselves or producing a suitable sponsor); (d) should express willingness to be resettled in Hong Kong; and (e) should not be able to meet the resettlement criteria of other resettlement countries.

It is noteworthy, however, that despite the financial incentives offered and although the refugees have been in camps for many years, they have demonstrated reluctance to volunteer for the programme (121 so far) in the hope of being offered a new home overseas. ${ }^{340}$

Once settled in Hong Kong, under any scheme, the refugees are considered in most respects as local residents, entitled to privileges and benefits available to native-born citizens. Indeed, full integration into Hong Kong society and economy has been the declared policy of the Government visà-vis any asylum-seeker granted permission to land and remain in Hong Kong. ${ }^{341}$

Yet, local integration as a solution to the refugee problem is not perceived as a viable option given general spatio-demographic constraints ${ }^{342}$, a growing local resentment against Vietnamese boat people ${ }^{343}$ as well as post-1997 considerations. With respect to the latter factor reference may be made to the 1984 Sino-British Joint Declaration (Annex I, Sec. XIV) un-

340. See S.MACKLIN, “Refugees Rejecting Resettlement in HK”, SCMP 14 Mar. 1990.

341. For further details see R.MUSHKAT, Asylum in Hong Kong (Raul Wallenberg Institute of Human Rights and Humanitarian Law, Sweden, 1990).

342. Hong Kong's population density is 5,192 persons per sq.Km, compared to 239 in the UK and 22 in the USA.

343. See results of poll: $84 \%$ for the abolition of first asylum policy, cited in FonG, "Call to Scrap First Asylum Policy", supra n.37. According to an earlier survey, $80 \%$ considered that Hong Kong should cease to be a port of first asylum and $55 \%$ supported a policy to tow newly arrived Vietnamese boat people back out to sea. See S.MACKLIN,"Poll Gives Support to Towing Boat People Back to Sea", SCMP 18 May 1989. 
der which no right of abode in the Hong Kong Special Administrative Region would be accorded to Vietnamese refugees who, by definition, are unable to comply with the requirement of (seven years) "ordinary residence $^{n}$ in the territory couples with the intention of making Hong Kong a "permanent place of residence."

It may further be noted that officials of the People's Republic of China have reiterated on various occasions that the refugee problem should be solved before the territory reverted to Chinese sovereignty. They have also stated that Beijing would not recognize the status of Vietnamese children born here before January 1983, even though they have been given the right of abode by Hong Kong in accordance with local immigration laws. ${ }^{344}$

\section{CONCLUSION}

An examination of Hong Kong's approach to the refugee issue from a comparative perspective highlights a number of interesting features of local policies in this area:

Because of British sensitivity to Chinese claims of sovereignty vis-à-vis the territory, the UK has not extended to Hong Kong the most significant international instrument in the area of refugee law - the 1951 Refugee Convention and its 1967 Protocol.

Consequently, notwithstanding the formal British link, the territory enjoys as much latitude as other Asian countries in its quest for ad hoc solutions to the problems it encounters in managing the refugee influx. Most Western nations have less room for manoeuvre in this respect but the UK has felt that, given the political constraints, it would be undesirable to deny the territory its Eastern identity. Britain itself, of course, has assumed a rather flexible posture regarding the incorporation of international conventions. It has been distinctly slow in translating them into domestic law, although it has not departed from their spirit. The Refugee Convention thus forms no part of UK law and is not enforceable as such by British courts. One could argue, however, that the UK legal environment has built-in mechanisms designed to prevent blatant abuses of human rights. After all, Britain is viewed as the cradle of liberal democracy, is blessed with well-functioning parliamentary institutions, has an independent judiciary and prides itself on having a protective legal culture. The "bureaucratic polity" of Hong Kong and its Asian counterparts are not endowed with such attributes.

344. See "Row over Refugees' Residency", SCMP 24 Mar. 1989; E.LAU, "Xu Says JLG Shall Decide Viet Rights", SCMP 29 Mar. 1989. 
In the absence of formidable external and internal constraints, the territory has responded pragmatically to the challenge posed by the mass arrival of asylum-seekers from Indo-China. Pragmatism has also characterised official attitudes in other parts of the region. Yet there seems to be an intangible difference between the Hong Kong brand of pragmatism and the general Asian pattern. The UK influence and the need to cultivate international goodwill have acted as a restraining force and have combined to propel the local authorities towards a position which may be conveniently described as one of "mildly progressive pragmatism." We hasten to add, however, that the pragmatic instincts have often proved stronger than the progessive values.

The evolution of Hong Kong's policy concerning the admission of refugees is a case in point. In the early phases, it was tinged with humanitarian considerations because the arrivals - mostly ethnic Chinese - were not perceived as a potential burden on the community. Subsequently, although stopping short of abandoning the first asylum principle, the authorities have become more concerned about the escalation in negative local sentiment towards the refugees and have sought ways to actively discourage arrivals. Nonetheless, fears of international condemnation and its possible adverse effects on the territory's economic performance have prevented them from resorting to the "push-back" practices common elsewhere in the region.

The result is an uneasy balance between assumed British standards and Asian realities. Again, however, it should be emphasised that the UK does not necessarily offer an ideal model in this respect. While the rule of non-refoulement has been incorporated into British immigration law, the restrictive approach to the notion of "first asylum", coupled with legislation imposing penalties on aliens without proper documentation, can be viewed as a subtle attempt to dissuade asylum-seekers from heading for UK shores.

Pragmatism has clearly been the dominant factor shaping Hong Kong policies regarding the standard of treatment accorded to refugees in the territory. Indeed, the authorities have openly stated that the objective of detention is to achieve humane deterrence and have left no scope for challenging this questionable measure. The conditions in detention centres, which leave much to be desired, also reflect the intention to render the environment as unattractive as possible to would-be asylum-seekers.

This is an area in which British and local practices diverge sharply. In the UK the grounds for detention are circumscribed and its implementation is subject to careful scrutiny. Equally important is the fact that aggrieved detainees have viable avenues for redress, both in Britain and through appropriate European channels. Such safeguards are lacking in 


\section{Hong Kong.}

Nor has the territory deemed it necessary to introduce UK type of safeguards into the refugee status determination process. Unlike in Britain, Hong Kong does not provide adequate administrative checks, guarantees anchored in judicial intervention and high-level political controls to counterbalance deficiencies in the screening procedures. Consequently, inexpert local immigration officials enjoy wide discretion in determining who qualifies as a refugee.

The territory can be credited with a slightly more progressive attitude with regard to the substantive criteria employed in the refugee status determination process. The local authorities have adopted the generally recognised criterion of "well-founded fear of persecution" embodied in the Refugee Convention as the yardstick for distinguishing "genuine refugees" from "illegal entrants". Unfortunately, however, the application of the criterion has been marked by a lack of humanitarian spirit, cultural biases, professional prejudices and misconceptions relating to the whole notion of human rights.

Pragmatic excesses are perhaps more apparent in Hong Kongs approach to "solutions" to the refugee problem. Local officials have defined the problem in terms of inconvenience to the territory and the need to minimize it rather than in terms of the plight of asylum-seekers fleeing from persecution. Their tactical responses therefore are geared towards securing the early departure of both refugees and non-refugees and do not directly address the question of the welfare of the individuals involved. Be that as it may, the solutions canvassed are not as extreme as those mooted by politicians elsewhere in the region.

It is reasonable to assume that at least one Hong Kong solution to the refugee problem, namely mandatory repatriation, would have found little support in the UK. Nonetheless, British policy-makers do not hesitate to promote it as appropriate for the territory. This conceptual duality cannot be easily dismissed as a crude double-standard. UK bureaucrats and their political masters apparently believe that British practices have to be modified to reflect local conditions. This quintessentially practical approach is understandable from an applied policy perspective but falls short of international legal expectations. A mildly progressive form of pragmatism is preferable to pure pragmatism of the Asian variety, yet it is contrary to the spirit and principles of human rights which Hong Kong can ill-afford to ignore.

Summer, 1990. 


\section{POSTSCRIPT}

While not presented by the Hong Kong Government as a change of policy, the recent introduction of an "orderly return programme" for asylumseekers who have been screened-out as non-refugees constitutes a departure from the status quo in a direction which may impinge on the territory's compliance with its international obligations. Under a Statement of Understanding concluded between the British, Hong Kong and Vietnamese Governments on 29 October 1991 "all Vietnamese asylum-seekers who were found under normal international rules to be illegal immigrants would be returned to Vietnam"; repatriation is to be carried out "in accordance with normal international practice."

No specific reference was made in the accord to the use of force but the Hong Kong authorities are inclined to interpret the relevant provisions as permitting force "if necessary. ${ }^{n 345}$ To the extent that the signatories' intention may be inferred, use of force had not been envisaged by the parties. British officials are said to have admitted that no agreement would have been forged were force contemplated. ${ }^{346}$ Vietnamese officials are quoted as stating that "Vietnam is ready to receive back the people who illegally left the country and who have not been accepted by any country as refugees in a way that respects their dignity, is orderly, safe and with the necessary financial assistance from the international organisations. ${ }^{3447}$

The international protest which followed the repatriation "under armed escort" of 51 asylum-seekers on 12 December $1989^{348}$ and British attempts at justification, emphasising the absence of force ${ }^{349}$ may also suggest the existence of an international standard of "non-use of force" in like circumstances.

At the same time, Hong Kong's latest operation ${ }^{350}$ in which "minimum force of restraint" was said to be employed ${ }^{351}$ - while triggering some criticism from opposition politicians in the UK ${ }^{352}$ and muted "regrets" from US

345. See S.Green, "How the Deal Was Struck", SCMP 2 Nov. 1991, Review 1.

346. Ibid.

347. Ibid.

348. See supra n. 273.

349. See supra $\mathrm{n} .278$.

350. The repatriation on 9 Nov. 1991 of 59 Vietnamese asylum-seekers.

351. See K.Griffin, "Viet Claims of Excessive Force Denied", SCMP 12 Nov. 1991 at p.2 (citing the Government's spokesman).

352. Which the British Foreign office attempted to defuse by asserting that " $t$ ] was carried out with as much sensitivity as possible" and that "[a]ll over the world illegal immigrants are compelled to return routinely, usually with no publicity and in many cases they are reluctant to go back." Cited in D. WALLEN, "Foreign Office Defends Move", SCMP 11 Nov. 1991 at p.2. 
officials $^{353}$ - has failed to provoke the kind of unequivocal international condemnation that engendered by the 1989 repatriation.

The milder response may be attributed to the lower level of sympathy towards the particular group of returnees involved, i.e., the so-called "double backers ${ }^{n} .{ }^{354}$ Given, however, current analogous practices in other parts of the world - including the forced return of Albanians by Italy, deportation of Tamils by the UK and the swift rejection of Haitians trying to land on US shores - the question arises whether relevant international standards are undergoing erosion.

It should nonetheless be emphasised that regardless of "hardening" attitudes towards asylum-seekers, ${ }^{355}$ the prohibition against the non-refoulement of refugees remains a binding norm. It is therefore particularly important to provide appropriate mechanisms for the determination of refugee status and secure a "profound and equitable" ${ }^{n 56}$ examination of each case. As noted earlier in this article, the screening procedures in the territory are not without flaws and should be "overhauled" if any scheme of involuntary return of "non-refugees" is to accord with "alternatives recognised as being acceptable under international practices" said to be contemplated under the Comprehensive Plan of Action of 13 June 1989.357

It may also be submitted that, apart from a plausible contention (based on the spirit in which the CPA was concluded) that such "alternatives" are

353. See K. Griffin and J.CookE, "US Regrets Use of 'Force' of Boat People, SCMP 9 Nov. 1991 at p.1.

354. Vietnamese who, having accepted UN cash aid to return home voluntarily, once there turned around and came back to Hong Kong a second time.

355. See, e.g., the Asylum Bill introduced by the British Government on 1 Nov. 1991 which aims at reducing what ministers call a "tide of bogus migrants" seeking political asylum. DAwny, "Plan to Tighten Rules of Asylum Create Stir", Financial Times 2-3 Nov. 1991. Note also the doubling (on 1 Aug. 1991) by Britain of fines imposed on airlines bringing migrants into the country without proper documentation: "UK Gets Tough on Asylum-Seekers", SCMP 2 Aug. 1991 at p.16. On 31 Oct. 1991, Germany gained the approval of 26 East and West European countries for its plan to tighten police control at border crossings); France endorsed tough labour measures to deal with migrants; Austria declared an end in May 1991 to automatic financial support for newly arriving Romanians and Bulgarians; Sweden uses emergency rules to keep out most migrants from Eastern Europe. T. CZucZKA, "Hugh Migration Chills Welcome, Hasten New Walls of Division", Bangkok Post, 1 July 1991 at p.13. In the Asia-Pacific region, Australia announced on 13 Aug. 1991 tough new regulations for refugee applicants ["Australia Gets Tough on China Refugees", SCMP 14 Aug. 1991 at p.14]; Malaysia has reaffirmed its policy of pushing Vietnamese boat people out to sea [R. VINES, "Malaysia Firm on Viet Policy, SCMP 22 July 1991 at p.9] as well as employing harsh screening procedures (in which $75 \%$ of Boat people who fled from Vietnam were judged to be non-refugees) ["Malaysia Reveals Refugee Protests" , SCMP 12 Feb. 1991]; Singapore has ceased even its limited admission policy (allowing Vietnamese boat people picked up at sea to land if third countries gave written guarantees of removal within three months) until all the asylum-seekers currently in camps in Singapore are resettled in accordance with commitments given [I.STEWART, "Singapore Issues Viet Ultimatum", SCMP 22 Oct. 1991 at p.17].

356. See Statement by the European Parliament on 22 Nov. 1991, cited in "EC Opposes HK Deal on Boat People , SCMP 22 Nov. 1991 at p.1.

357. Article 14, CPA, supra n. 72. 
to be decided in a multilateral fashion, they are viewed as a means of last resort "if after the passage of a reasonable time it becomes clear that voluntary repatriation is not making sufficient progress towards the desired objective. ${ }^{n 358}$ While this stipulation in the CPA agreement allows governments a wide scope for subjective judgments, the increasing numbers of asylum- seekers in Hong Kong volunteering to return to Vietnam ${ }^{359}$ ought to militate against the deployment of extreme measures. ${ }^{360}$

It is further arguable that although no enforceable right to asylum is yet recognised by the international community, asylum-seekers who have languished for several years in refugee camps merit special consideration on humanitarian grounds not to be repatriated to a country which they fled at a great risk to their lives. ${ }^{361}$ Perhaps some such notion underlies the Government's decision to apply the orderly return programme "initially to all new arrivals found to be illegal immigrants. ${ }^{362}$

Finally, whether mandatory or voluntary, repatriation must not be implemented unless there are sufficient assurances in place that no returnees would be subjected to punitive or discriminatory treatment. As restated by the Hong Kong Government, "[t]he Vietnamese Government has guaranteed that no illegal immigrant who returns to Vietnam will face persecution and that it will continue to facilitate monitoring of returnees by the UNHCR to ensure that these guarantees are fully respected. ${ }^{363}$ Questions nonetheless have been raised concerning the compliance of provincial authorities with Central Government's undertakings ${ }^{364}$ in a country still widely regarded as an oppressive entity. Given the nature of the regime, it is imperative that precautions be taken not to upset the delicate balance between pragmatic urges and progressive values.

\section{November 1991.}

358. Ibid.

359. Over 11.000 people had already returned under the UNHCR's voluntary repatriation scheme. See Government Secretariat Press Release of 29 Oct. 1991.

360. Note, however, the Government's "placating" approach in pointing out that the "voluntary repatriation would continue" and "[e]very encouragement would be given to non-refugees to return home under this programme." See Press Release, supra n. 359.

361. It may be instructive to note that "elementary considerations of humanity" have been regarded by the International Court of Justice as part of "general and well recognised principles" in which international obligations may be grounded. See Corfu Channel case, [1949] ICJ Rep. 4, at p.22.

362. Press Release, supra n. 259.

363. Press Release, supra $n$. 359. It was also stated that " $t$ there had been not a single substantiated case of persecution of anyone who had returned [under the UNHCR voluntary repatriation programme], Ibid.

364. See A.BoYd and F.MACMAHON, "Returnees Face Viet Retaliation", SCMP 23 Oct. 1991 at p.1 (reporting on plans by Haifong officials to punish "doublebackers"). 